\title{
Forecasting Global Developments and Challenges in Olive Oil Supply and Demand: A Delphi Survey from Spain
}

\author{
Samir Mili ${ }^{1, *(D)}$ and Maria Bouhaddane ${ }^{2}$ \\ 1 Institute of Economics, Geography and Demography (IEGD), Spanish National Research Council (CSIC), \\ Albasanz 26, 28037 Madrid, Spain \\ 2 VetAgro Sup, Agronomic Campus of Clermont-Ferrand, 89 Avenue de l'Europe, 63370 Lempdes, France; \\ maria.bouhaddane@hotmail.fr \\ * Correspondence: samir.mili@csic.es; Tel.: +34-916-022-399
}

Citation: Mili, S.; Bouhaddane, M. Forecasting Global Developments and Challenges in Olive Oil Supply and Demand: A Delphi Survey from Spain. Agriculture 2021, 11, 191. https://doi.org/10.3390/ agriculture11030191

Academic Editors: Primo Proietti and Tiziano Caruso

Received: 7 February 2021

Accepted: 22 February 2021

Published: 26 February 2021

Publisher's Note: MDPI stays neutral with regard to jurisdictional claims in published maps and institutional affiliations.

Copyright: (C) 2021 by the authors. Licensee MDPI, Basel, Switzerland. This article is an open access article distributed under the terms and conditions of the Creative Commons Attribution (CC BY) license (https:/ / creativecommons.org/licenses/by/ $4.0 /)$.

\begin{abstract}
Forecasting future supply and demand is a topical subject in the olive oil sector due to its relevance for decision making and the lack of comprehensive and consensual estimates at the global level. This study aims at overcoming this gap in research by providing a foresight of global supply and demand for olive oil for the years to come. We use the Delphi technique to estimate the expected annual growth rates in the olive oil production and consumption worldwide as well as their likely impact on Spanish exports by 2025. Another key objective of the study is to elicit expert judgements on the factors that are likely to shape the predicted changes as well as the international challenges ahead. Results suggest substantial future increases in production in new-producing countries, in parallel with a slower growth in the European traditional suppliers whose focus will increasingly be placed on quality and sustainability rather than quantity. In addition, a significant growth in the world's demand for olive oil is expected in non-traditional markets, which will be driven by greater awareness of the positive health and sustainability attributes of this product, jointly with the changes in lifestyles and rising incomes of several consumer segments. These emerging markets offer promising prospects for the international expansion of olive oil companies. Future international challenges facing the olive oil industry include new market entry, worldwide product promotion, quality standards' harmonization, enacting trade facilitation schemes, and dealing with the COVID-19 impacts. Findings improve market predictability and transparency, and ultimately support decision-making and strategic planning in the olive oil sector.
\end{abstract}

Keywords: judgmental forecasting; Delphi technique; supply; demand; global market; olive oil

\section{Introduction}

Effective planning in agri-food markets is heavily reliant on the accuracy and consistency of supply and demand forecasts, and olive oil is no exception. In the olive sector, predicting future developments in global supply and demand is a highly relevant topic [1-4] where there is a lack of comprehensive, consistent, and consensual estimates at the international level. Dedicated academic studies that develop forecasts addressing the entire relevant countries and major critical factors in the olive oil global market remain scarce, resulting in substantial uncertainties and discrepancies in this domain. To our knowledge, the only published, readily available prospects concerning the evolution of the olive oil market in the years to come are those presented in the annual "EU Agricultural Outlook for the Agricultural Markets and Income". The latest EU agricultural outlook refers to the horizon 2020-2030 [5]. However, the EU prospects remain highly aggregated and are not global in nature since they are focused only on the EU Member States.

Therefore, this study aims at contributing to fill this knowledge gap by producing a methodologically sound analysis on the future of the global supply and demand for olive oil in the upcoming years (horizon 2025), covering the whole spectrum of relevant countries involved in this sector ranging from traditional Mediterranean players to new 
international actors. For this purpose, we use the Delphi technique to estimate the expected annual growth rates in the olive oil production and consumption worldwide, as well as their likely impact on exports originating from Spain, which is the world's leading country in olive oil production, exportation, and market influence. Another key objective of the study is to elicit expert judgements on the factors that are likely to shape the predicted changes. The study also seeks to uncover the challenges and opportunities that lie ahead with regard to international trade, and assess whether more ambition is required to achieve further improvements in the international olive oil markets.

The reminder of this paper is arranged as follows. In Section 2, an analytical review is undertaken of the global market for olive oil and its key trends to establish the broader framing of this study. Section 3 develops the conceptual framework and the methodology adopted for information gathering. The main results obtained in the Delphi survey are depicted in Section 4. This is followed by discussion in Section 5 and conclusion in Section 6.

\section{Review of the Global Market for Olive Oil}

Before elucidating the analytical framework for this study, it is necessary to briefly outline the main features of the global market for olive oil. Like most of agri-food sectors, the global olive oil industry has been significantly affected by increasing market globalization and continuous socioeconomic and technological changes that have shaped the whole agribusiness environment towards further diversification and competition while opening up new opportunities worldwide [6,7]. In this context, the global production of olive oil has experienced a progressive growth over the past two decades in response to the increasing public and private interest in the product. Extensive economic and technical efforts have been engaged in restructuring the existing plantations and the establishment of new orchards in many olive-growing countries, along with the improvement of the cultural and harvesting practices and the modernization of production processes $[2,6,8,9]$. These efforts impacted positively production, and resulted in substantial gains in productivity and quality standards.

Data provided by the International Olive Council (IOC) [10] show that the world's olive oil production reached an average of 2.87 million tons in the period between crop years 2005-2006 and 2019-2020 (crop year is established for olive oil from 1 October year $t$ to 30 September year $t+1$ ), of which $72 \%$ was produced in the European Union (EU). Production in Spain, Italy, and Greece accounted for approximately 2 million tons, representing $96 \%$ of the EU olive oil production. However, the world's production has been growing at a slower pace over the stated period, where the annual growth rate of global production was about $2 \%$ in comparison with $4 \%$ recorded between the crop years 1994-1995 and 2004-2005. This relative decline is directly linked to the slowdown in the growth of EU production, where significant output increase in Spain and Portugal has been offset by lower production in Italy and Greece.

Meanwhile, production grew rapidly during 2005-2020 in non-EU Mediterranean countries such as Tunisia, Turkey, and Morocco, where production was incited by domestic and foreign investment. In these countries, olive-growing area has increased and yields have improved significantly through irrigation and modern harvesting methods. The same trend has been experienced since the mid 1990s in new producing countries outside the Mediterranean region, such as Chile, Australia, and Argentina, which benefited from intensive and efficient production methods and have emerged as important sources of olive oil [11-13]. IOC data indicate that production from these non-traditional suppliers increased by 8\% annually between 2006-2007 and 2019-2020.

On the demand side, world consumption of olive oil has also witnessed a substantial growth in the course of the three past decades as the product's appeal spread beyond the Mediterranean, thereby increasing 1.8-fold in volume between 1995-1996 and 2019-2020 [10]. Demand expansion has been particularly induced by the public and private promotional campaigns carried out in the non-traditional markets, which contributed 
greatly to stimulating the interest for olive oil and raising awareness of its health and environmental benefits $[6,8]$.

Traditionally, the evolution of the global consumption of olive oil has been primarily determined by demand levels in the EU, and more specifically in the EU's main producing countries. Between 1990-1991 and 2004-2005, the average olive oil consumption in the EU amounted to 1.6 million tons, representing around $72 \%$ of world consumption. However, this share fell to 58\% during the period 2006-2007/2019-2020, as consumption in major EU producer countries-which also are the major consumers (Spain, Italy, and Greece) - declined slightly in 2000-2007 and more markedly during the 2008-2015 economic recession period. Conversely, the opposite trend was seen in the EU non-producing countries where consumption increased rapidly in countries such as the United Kingdom (UK) and Germany. Broadly speaking, this phenomenon has been taking place chiefly in non-IOC member countries, whose share in the global olive oil consumption has more than doubled, rising from $11 \%$ in $1995-1996$ to $26 \%$ in 2019-2020. Among these countries, the United States (US) has seen the most remarkable growth as the quantity of olive oil consumed in the US market has tripled over the past 20 years, reaching 330,000 tons in 2019-2020 (of which 315,000 tons are imported), thereby taking over Greece's position as the world's third-largest olive oil-consuming country behind Italy and Spain.

On a per capita basis, Greece maintains its world-leading position, although it has seen its annual per capita consumption reduced by half from $24 \mathrm{~kg}$ in 2005-2006 to $12 \mathrm{~kg}$ in 2019-2020. Spain is second with an annual consumption of $10.3 \mathrm{~kg}$ per capita, followed by Italy $(9.44 \mathrm{~kg})$ and Portugal $(7.34 \mathrm{~kg})$ where per capita consumption also declined in comparison with its level in the previous decade. In contrast, US per capita consumption, although barely one kg per year, still has large room for growth and, given the size of the US market, even very small increases in this volume would have a significant impact on total US consumption and imports [12,14]. Likewise, while per capita consumption in other importing countries, such as Japan $(0.44 \mathrm{~kg})$, Brazil $(0.37 \mathrm{~kg})$, and China $(0.03 \mathrm{~kg})$, is still low in quantitative terms, a significant potential for its growth exists in the future.

With respect to international trade, olive oil trade mostly takes place between the Mediterranean countries, and is led by the EU, mostly Spain and Italy. More than half of the global olive oil exchanges occurs within the EU, as during 2011-2012/2019-2020, annual intra-EU exports accounted for about 1 million tons on average, while annual EU exports to the rest of the world reached an average of 560,000 tons over the same period [15]. Spain is by far the world's leading exporting country, with a volume of 880,000 tons (including intra-EU) exported on average during 2011-2012/2019-2020, thereby accounting for about $50 \%$ of global exports. Seventy percent of Spanish exports were destined for the EU market. Italy ranks second, accounting for about $20 \%$ of global exports over the same period, of which close to one-third were sent to the US. Other EU countries, mainly Greece and Portugal, together accounted for about $13 \%$ of global exports over the same period. Major markets for Greece are within the EU, while about half of Portuguese olive oil exports are sent to Brazil.

Tunisia is the third largest world exporter, and has accounted on average for as much as $8 \%$ of world exports since 2011, with an exceptional record of 304,000 tons of olive oil exported during the 2014-2015 crop year, as a consequence of an exceptionally good production year concurring with a heavy drop in production in Spain and Italy. Among the other producing countries, data show that Turkey is also a relevant actor on the global olive oil market albeit with significant fluctuations in production. Syria and Morocco are important producers, however their presence in the export market is limited since their production is similar to their domestic demand. Moreover, Argentina, Australia, and Chile have emerged in the past decade as new export-oriented countries, however their export volume is still very low.

Similarly, imports are dominated by the EU where most trade occurs. During 20112012/2019-2020, about 90\% of the olive oil imported by EU countries was sourced from other EU countries, and the rest coming mainly from Tunisia and Morocco. In addition to 
proximity to the EU market, several non-EU Mediterranean countries receive preferential access to the EU market and are given duty-free tariff quotas [16]. Tunisia has the highest quota (56,700 tons), and it has been granted an additional quota of 35,000 tons annually for the years of 2016 and 2017 [17].

Italy is the world's leading importer country, supplied almost totally by Spain, Greece, and Tunisia. It accounts for $28 \%$ and $46 \%$ of global and EU olive oil imports, respectively, with an average of 520,000 tons of olive oil imported during 2011-2020, consisting largely of bulk product. Within the EU, the second largest importer is France with an average of 115,000 tons imported during the reported period.

The US is the largest importer outside the EU, with an average of 306,000 tons imported during the last five years. The US olive oil imports grew significantly since the early 1990s, and tripled in volume over the past 20 years. It is worth mentioning that in the last two decades, there has been a growing shift in the preferences of US consumers in favor of higher quality olive oil, reflecting their increased awareness of the product quality attributes. This is evidenced by the fact that in 1993-1994 virgin olive oil represented 32\% of total US imports, a share that expanded to 70\% in 2019-2020. Italy and Spain have been traditionally the major suppliers of the US Market. However, their share in US imports has fallen over the last decade, mostly because of the emergence of Tunisia, Morocco, Argentina, and Chile as suppliers of the US market at the expense of Italy in particular [12]. Other major olive oil-importing countries are Brazil, Japan, Canada, China, and Australia. Japanese imports grew over $6 \%$ annually over the past decade, while imports of Brazil and Canada recorded an annual increase by $6.5 \%$ and $4.9 \%$, respectively, during the same period. The highest growth was seen in China, since its imports grew by $14 \%$ annually between 2010 and 2020.

Another defining feature of the international olive oil market is the absence of an official, universally recognized price benchmark. There are, instead, more or less representative regional markets. Most representative markets determining olive oil prices are in Bari (Italy), Chania (Greece), and Jaén (Spain), where almost 70\% of the world's olive oil is traded [15]. Price determination in these markets not only has a decisive impact on prices in other EU regions but also influences vastly export prices in non-EU producing countries. Usually, while prices in Jaén and Chania track each other quite closely, Bari prices tend to be higher than the others, in particular in the extra-virgin and virgin categories. This divergence is mainly due to the fact that prices in Bari reflect in more extent local supply and demand conditions and production costs. Since producer prices vary according to supply, demand and stock levels, they tend to be higher in deficit markets (Italy) than in surplus markets (Spain and Greece). Prices also reflect the quality of olive oil and are different for each product category (extra-virgin, virgin, lampante) [18-20].

\section{Research Methodology}

\subsection{Research Design and Steps}

Making informed projections about the future trends of the global market for olive oil is crucial for strategic decision-making and planning, given the growing complexity and uncertainty in international market conditions. One pathway to tackle uncertainties and explore the potential actions needed in the future is the use of foresight techniques allowing the development of reliable near and longer-term forecasts within highly volatile settings. Therefore, this study utilizes the Delphi method, which is one of the best-known and widely used forecasting techniques based on the collective cognition of a selected panel of experts on matters relating to future events [21-25]. This method has proved to be effective in producing accurate long-term predictions [21,26-28]. There are no clear patterns in Delphi literature explaining the choice of the prediction time horizon, probably due to the lack of relevant studies on the pros and cons of using different time scales [29]. In this study, the time frame up to 2025 was established as this allowed some element of envisioning probable futures whilst still remaining within a reasonable frame of reference for experts, thereby contributing to more realistic forecasts. 
Delphi also can significantly improve the chances of obtaining unbiased forecasts that will likely improve decision-making [30,31]. Moreover, Delphi forecasts are not baseline projections where policies remain unchanged, since experts account for changes in settings. This feature makes the Delphi technique particularly adequate for judgmental foresight in sectors like olive oil that are subject to rapid and multi-dimensional changes often difficult to quantify.

The key characteristics of the Delphi method are (i) anonymity of the participants in order to avoid the persuasive effect of dominant members of the group [32]; (ii) an iterative process: Delphi runs in two or more rounds of structured questionnaires to allow information exchange within the panel $[27,31,33,34]$, and the process is repeated until the stability of the responses is achieved, irrespectively of whether or not a consensus is reached [35]; (iii) controlled feedback: After each round, the estimates provided by the respondents are summarized statistically, and items object of discordance are delivered back to the experts for re-assessment; and (iv) group statistical response, which can be presented either numerically or graphically and usually comprises measures of central tendency (median, mean), dispersion (interquartile range, standard deviation, coefficient of variation), and/or frequency distribution [36]; this characteristic ensures that the contributions of all members are present in the group response.

In this study, we applied the Delphi method in four steps. First, the research objectives and the conceptual model were formulated. Then, a final questionnaire was prepared after several preliminary versions, and a rigorous selection of the participating experts was performed. Subsequently, the Delphi survey was implemented in two rounds during 2017. We used two rounds as a result of the satisfactory level of stability of responses attained in the second round, which makes further rounds fruitless according to the literature on ending the iterative process in Delphi studies (see Section 3.2). Finally, the major findings of the study were portrayed and analyzed.

Figure 1 summarizes the main components specified in the study. Basically, they include production technology, geographical distribution of supply and demand, globalization, price competition, and consumer behavior. The selected factors represent a simplified conceptualization of the problem posed in the Delphi based on the extant literature on market dynamics and structural changes within the global olive oil industry outlined above. These components are hypothesized to be the major factors of change that will shape the global supply and demand for olive oil in the future. In order to gain explanatory and predictive power, the internal consistency of the suggested framework was enhanced through ensuring the maximum of theoretically and empirically grounded relationships among the variables in the model.

The panelists were carefully selected on the basis of their background diversity and highest level of knowledge, experience, and responsibility in their respective organizations (see the profile of participants in Table 1). They represent the following three expert groups: (1) Most important olive oil companies and business associations, (2) national and international public administration including the European Commission and the IOC, and (3) academia and research representatives. Our aim was to form a representative, top-expert panel in the field that approaches the olive oil market prognostication from different perspectives in order to give a comprehensive and compelling view of the issues under scrutiny. 


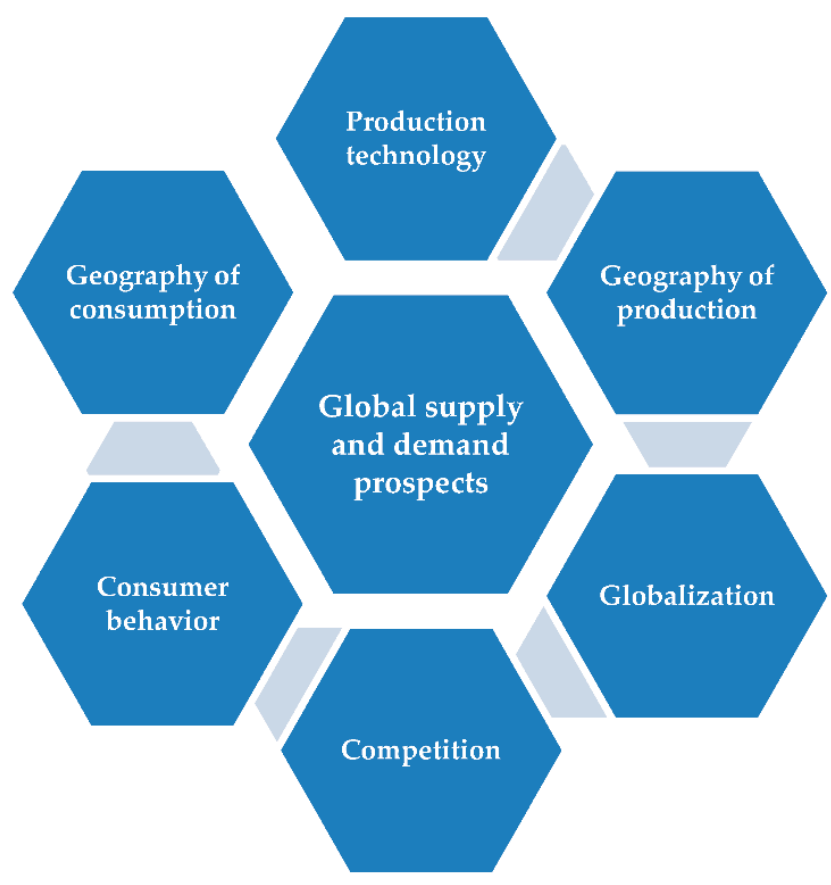

Figure 1. Main foresight factors in the Delphi study. Source: The authors.

Special attention was paid to drafting the questionnaire since it is the other central piece of the Delphi study together with the expert panel. The questionnaire was carefully constructed to address the different aspects synthetized in the analytical model. Several preliminary versions were elaborated to improve the design process through identifying and removing linguistic and conceptual ambiguity. The questionnaire comprises a set of semi-open questions relating to the likely future scenarios of the global olive oil industry in terms of supply, demand, and international trade challenges. Semi-open questions are questions where the respondents are required to evaluate a set of pre-prepared response options, with the possibility of adding their own freely reported perception of the question theme [37]. This type of question combines open and closed question formats [38,39], allowing the possibility of eliciting different assessments of the offered alternatives and/or new perspectives from the respondents. In our questionnaire, each question contains a section for including additional comments on aspects that might have remained undiscovered. Compared to the open-ended questions, semi-open questions require less time to respond, thereby making the task easier for the experts and allowing the maximization of the rate of response.

In the questionnaire, the expected annual growth rates in olive oil production and consumption worldwide were assessed according to a four-point percentage equivalence scale as follows: $1=$ very moderate increase $=0-2 \% ; 2=$ moderate increase $=2-5 \% ; 3=$ sharp increase $=5-10 \% ; 4=$ very sharp increase $=>10 \%$. The four-item scale adopted is a discreteordinal scale implying a ranking of the different alternatives in a consistent sequence [40,41], thus, for example, "sharp increase" denotes higher relevance than "moderate increase". Owing to the fact that ordinal scales provide mainly ordinal classifications [42], they can be used in association with ordinal equivalence measures that might be numerical values or intervals as ranges of plausible values (for growth rate in our case) to obtain quantified estimated linked to each category of the scale $[43,44]$. Note that many authors including Baker et al. [45] and Labovitz [46] have shown empirically that it matters little if an ordinal scale is treated as an interval scale. The associated interval scale used in this study is additive and progressive with different amplitudes for successive intervals. The range of values assigned to the intervals take as a reference the historical magnitudes of growth in the global olive oil supply and demand (see Section 2), assuming at the same time that it 
might be easier for the experts to predict an interval of values than a punctual value, which could potentially increase the predictive performance of the panel.

Table 1. Profile of Delphi participants.

\begin{tabular}{|c|c|c|c|}
\hline Participant & Expert Group & Profile/Expertise & Scope of Activity \\
\hline 1 & \multirow{6}{*}{$\begin{array}{l}\text { Olive oil industry and } \\
\text { business associations }\end{array}$} & $\begin{array}{l}\text { President and Chief Executive Officer of a large } \\
\text { Spanish olive oil company }\end{array}$ & Mostly international \\
\hline 2 & & $\begin{array}{l}\text { General Director for marketing and exports of a } \\
\text { large international olive oil company }\end{array}$ & Mostly international \\
\hline 3 & & $\begin{array}{l}\text { Director of Department for strategies of a large } \\
\text { Spanish olive oil company }\end{array}$ & Spain, international \\
\hline 4 & & $\begin{array}{l}\text { General Director of the Spanish Association for } \\
\text { Olive oil Industry and Exportation }\end{array}$ & Spain, international \\
\hline 5 & & $\begin{array}{l}\text { Responsible for olive oil sector in the Spanish } \\
\text { Union of Small Farmers and Ranchers }\end{array}$ & Spain, international \\
\hline 6 & & $\begin{array}{l}\text { Responsible for olive oil sector in the Spanish } \\
\text { Agricultural Association of Young Farmers }\end{array}$ & Spain, international \\
\hline 7 & \multirow{4}{*}{ Public administration } & $\begin{array}{l}\text { Former Executive Director of the International } \\
\text { Olive Council }\end{array}$ & International \\
\hline 8 & & $\begin{array}{l}\text { Head of Department of olive statistics of the } \\
\text { International Olive Council }\end{array}$ & International \\
\hline 9 & & $\begin{array}{l}\text { Specialist in olive oil market in the } \\
\text { European Commission }\end{array}$ & EU, international \\
\hline 10 & & $\begin{array}{l}\text { Specialist in olive oil market in the Spanish } \\
\text { Ministry of Agriculture }\end{array}$ & Spain, international \\
\hline 11 & \multirow{7}{*}{ Academia and research } & $\begin{array}{l}\text { Senior Researcher in a Spanish public research } \\
\text { organization, specialist in olive oil and } \\
\text { food markets }\end{array}$ & Spain, international \\
\hline 12 & & $\begin{array}{c}\text { Senior Researcher in a Spanish public research } \\
\text { organization, specialist in olive oil and } \\
\text { food markets }\end{array}$ & Spain, international \\
\hline 13 & & $\begin{array}{c}\text { Senior Researcher in a Spanish public research } \\
\text { organization, specialist in olive oil and } \\
\text { food markets }\end{array}$ & Spain, international \\
\hline 14 & & $\begin{array}{l}\text { University Professor, specialist in olive oil and } \\
\text { agri-food marketing }\end{array}$ & Spain, international \\
\hline 15 & & $\begin{array}{c}\text { University Professor, specialist in olive } \\
\text { oil marketing }\end{array}$ & Spain, international \\
\hline 16 & & $\begin{array}{c}\text { University Professor, specialist in olive } \\
\text { oil marketing }\end{array}$ & Spain, international \\
\hline 17 & & $\begin{array}{c}\text { University Professor, specialist in olive } \\
\text { oil market }\end{array}$ & Spain, international \\
\hline
\end{tabular}

Source: The authors.

The likely impact of the expected growth in supply and demand on Spanish exports was evaluated on a five-point Likert scale [47] ranging from 1 (minimum valuation) to 5 (maximum valuation). As for the factors shaping the predicted growth and the challenges ahead, a five-point Likert scale also was used to assess the degree of importance that the experts assign to each item. This scale is the most commonly used for the study of continuous properties-especially those relating to attitudes and judgements, due to the simplicity of its theoretical structure that is traditionally represented by a series of individual statements on which the respondent has to express his/her assessment [48,49]. 
The questionnaire was sent by email accompanied by an invitation letter to 13 experts in the first round and 32 experts in the second round. Table 2 depicts the response rates in the two Delphi rounds. The response rates and the absolute number of responses can be considered fair; the effective responses exceed the minimum of seven experts established in literature for this type of surveys, considering that in Delphi studies, the forecast error decreases for each expert added until reaching a certain number of participants, after which gains in forecast accuracy become marginal or even negative [50].

Table 2. Response rates of expert groups.

\begin{tabular}{lcccc}
\hline \multicolumn{1}{c}{ Expert Group } & \multicolumn{1}{c}{ Round 1 } & \multicolumn{2}{c}{ Round 2 } \\
\cline { 2 - 5 } & $\mathbf{n}$ & $\mathbf{\%}$ & $\mathbf{n}$ & \% \\
\hline (1) Industry and business association experts & 1 of 3 & 33.33 & 6 of 21 & 28.57 \\
(2) Public administration experts & 2 of 3 & 66.66 & 4 of 4 & 100 \\
(3) Academia and research experts & 6 of 7 & 85.71 & 7 of 7 & 100 \\
Total & 9 of 13 & 69.23 & 17 of 32 & 53.13 \\
\hline
\end{tabular}

Source: The authors.

It should be noted that there is no established optimal number of experts in Delphi studies. The panel size is not required to be a statistically representative sample since the panel representativeness is based on the quality of judgements rather than the number of respondents [31,33,51-56]. Hallowell and Gambatese [57] stated that most Delphi studies used 8 to 16 panelists and suggested a minimum of 8, Okoli and Pawlowski [54] recommend a panel of 10 to 18 experts, Landeta [50] and Powell [55] suggested that the number of participants should be between 7 and 50 or over, whereas Turoff and Hiltz [58] reported that Delphi studies were commonly applied to groups of 30 to 100 individuals. In a review made by Mukherjee et al. [31], 19 out of 31 studies that had mentioned the number of respondents had fewer than 20 respondents. In all the overmentioned studies, the small number of experts has not been identified as a limitation if the panel is adequately balanced, diversified, and truly expert, irrespectively of the type or the geographical coverage of the study.

In this study, in order to strengthen the consensus achieved on the first round, it was decided to extend the expert panel in the second round by including additional experts while keeping the representation among the different professional backgrounds as balanced as possible. This is made possible by the flexibility of the Delphi method, which allows direct intervention both on the content of the questionnaire, and on the panel of experts by means of new inclusions over successive rounds [50].

\subsection{Data Analysis}

The analysis of the results involves both a quantitative analysis of the distribution of the responses as well as a qualitative analysis consistently integrating the comments provided by the experts. The quantitative analysis consists of the use of descriptive statistics to determining the central position of the responses and quantifying the consensus degree. In line with other Delphi studies such as $[3,29,59]$, we used the mean as a measure of the central tendency of responses. The use of the mean allows the identification of the factors deemed most relevant and influential.

In addition, we used the coefficient of variation (CV) to appraise the level of consensus among the participants. According to Saldanha and Gray [60], consensus-which can be either agreement or disagreement on a statement-is defined as a percentage higher than the average percentage of majority opinion (i.e., above $50 \%$ ). The coefficient of variation is a robust and widely used measure of dispersion that is independent of the units of the variable (appropriate for comparing variability across variables measured in different units), and shows the extent of relative variability in relation to the mean value of responses. Consensus is reached if the CV is less than a predetermined value. In Delphi literature, it is 
conventionally accepted that a CV below 0.5 is a reasonable indicator of consensus [3,61,62]. In the present study, we qualified the degree of consensus according to the following scale: $\mathrm{CV} \leq 0.3$ = very high degree of consensus; $0.3<\mathrm{CV} \leq 0.5=$ high degree of consensus; $0.5<\mathrm{CV} \leq 0.7=$ low degree of consensus; $0.7<\mathrm{CV} \leq 1=$ very low degree of consensus. The cut-off point was set at levels below 0.3 in the first Delphi round in order to build a quite strong consensus, and below 0.5 in the second round. In the first round, the statements that did not reach the established threshold for consensus were included in the second round for re-evaluation. Moreover, in order to test the stability of responses, we checked for changes in the relative CV between the two rounds, as suggested by Dajani et al. [63].

The responses obtained in the second round can be considered highly satisfactory as they present a great degree of internal consistency and a high level of agreement between responses. A robust consensus was achieved as the degree of dispersion expressed in terms of $\mathrm{CV}$ was below 0.5 for all the items in the questionnaire, and below 0.3 for the majority of them. In addition, no substantial differences were observed in the $\mathrm{CV}$ values between the first and the second round, with the majority of items displaying a change in CV lower than $15 \%$. This complies with the stability criterion between rounds suggested by von der Gracht [36], Dajani et al. [63], and Scheibe et al. [64] that allows the ending of the iterative survey process. Moreover, the differences across the three expert groups were examined by comparing their respective means. No significant discrepancies were noted in the average opinions expressed by the different expert groups.

\section{Survey Findings}

The main results derived from the second and final round of the Delphi survey are subdivided into three interconnected areas following the structure of the questionnaire. The two first areas present the expected trends in the global supply and demand for olive oil and their respective impact on Spanish exports. The third area focuses on the challenges related to olive oil international trade in the coming years.

\subsection{Expected Trends in the Global Supply for Olive Oil}

Figure 2 summarizes the magnitude of increase and degree of impact allocated by the experts to each of the countries where olive oil production is expected to grow in the upcoming years. The results are presented in terms of the overall means and their corresponding coefficients of variation. The means for each group of participants are depicted in Table A1.

According to experts, substantial increases in production are likely to be recorded in the countries that have traditionally been non-producers in the upcoming years. The highest rate of growth was attributed to China, whose production is expected to experience a sharp increase by growing at a rate greater than $5 \%$ annually. In China, the total olive plantation areas are expected to increase from 66,400 hectares in 2016 to approximately 193,400 hectares by 2030 [65]. Moreover, moderate to strong annual increase rates will likely be registered in the United States, Australia, Argentina, and Chile, and to a lesser extent in South Africa.

Production is expected to grow at a slower rate in the EU than in the non-EU Mediterranean producer countries. It is likely that Morocco, Tunisia, and Turkey will register the highest increases in production in the Mediterranean region, followed by Portugal and Spain, whereas Italy and Greece are expected to show the lowest growth rates in the coming years. 


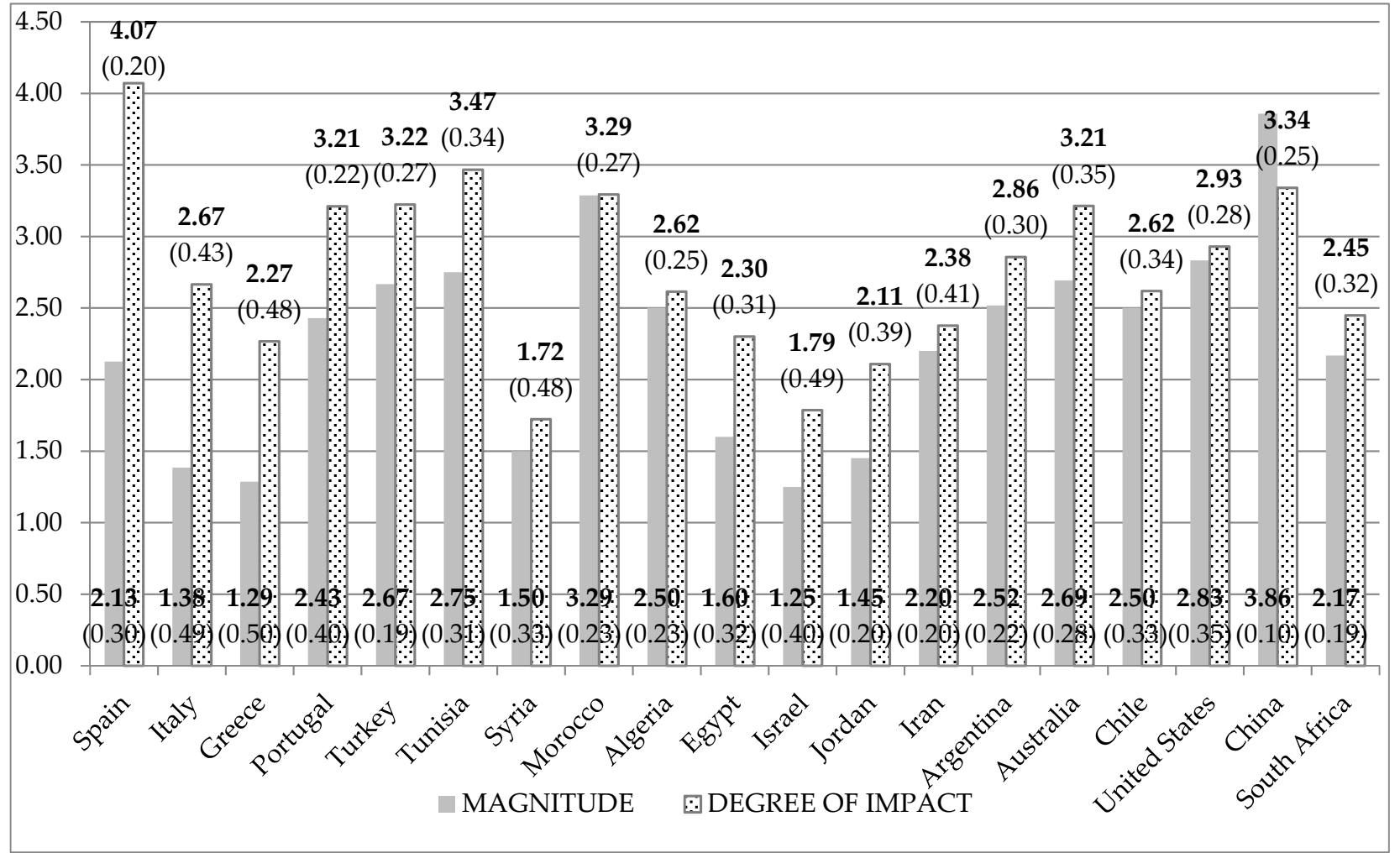

Figure 2. Magnitude of annual increase in world supply of olive oil and its degree of impact on Spanish exports (overall mean and coefficient of variation). Note: Values represent (a) mean annual growth on a four-point scale from "very moderate increase" to "very sharp increase" (figures down in the chart), and (b) mean impact on a five-point scale from "insignificant" to "very significant" (up in the chart). Coefficient of variation values are displayed in parentheses.

Differences across countries are not limited to the magnitude of the future increase rates, but extend to their potential impact on the Spanish olive oil exports. The experts estimate that the greatest impact will originate from the production growth in Spain (this is despite the relatively lower magnitude of this growth compared to other counties, since the Spanish production capacity is the highest worldwide, where small growth rates in production generate large impacts on exports), Tunisia, China, and Morocco, whereas a lower degree of impact has been assigned to Italy and Greece. In the case of China, the domestic output is still very low in volume terms. The olive oil available on the Chinese market is imported mainly from the Mediterranean countries ( $40 \%$ is sourced from Spain) and sold at prices attaining 10 times the price of other vegetable oils [66]. This implies that substantial increase in the domestic supply would significantly reduce the volumes imported, especially since the locally produced olive oil are more affordable for the Chinese consumers.

As for the conditioning factors of the above-mentioned production increases, there is a widespread agreement that the potential growth in production is largely attributed to greater efficiency and productivity. The results in Table 3 suggest that potential growth will be mainly determined by the improvement of production conditions (cultivation techniques, modern systems of irrigation, intensive production methods, etc.), and a greater efficiency in the use of means of production. New plantations in traditionally non-producing countries are expected to play a key role in the future growth of olive oil supply globally, in particular since a growing interest, awakened by the favorable commercialization perspectives in non-traditional markets, is being manifested for olive cultivation. 
Table 3. Conditioning factors of the future increase in the global olive oil supply.

\begin{tabular}{|c|c|c|c|c|}
\hline & $\begin{array}{l}\text { Industry Experts and } \\
\text { Representatives of } \\
\text { Business Associations }\end{array}$ & $\begin{array}{c}\text { Representatives of } \\
\text { Public Administration }\end{array}$ & $\begin{array}{c}\text { Representatives of } \\
\text { Academia }\end{array}$ & $\begin{array}{l}\text { Overall Mean }(\bar{x}) \text { and } \\
\text { Coefficient of } \\
\text { Variation }(c v)\end{array}$ \\
\hline $\begin{array}{l}\text { Improvement of } \\
\text { production conditions } \\
\text { (cultivation techniques, } \\
\text { modern systems of } \\
\text { irrigation, intensive } \\
\text { production methods) }\end{array}$ & 4.20 & 4.75 & 4.29 & $\begin{array}{c}\bar{x}=4.38 \\
\mathrm{cV}=0.14\end{array}$ \\
\hline $\begin{array}{l}\text { Greater efficiency in the } \\
\text { use of means of } \\
\text { production }\end{array}$ & 4.00 & 4.00 & 3.71 & $\begin{array}{c}\bar{x}=3.88 \\
\mathrm{cv}=0.16\end{array}$ \\
\hline $\begin{array}{l}\text { New plantations in } \\
\text { traditionally } \\
\text { non-producing } \\
\text { countries }\end{array}$ & 4.17 & 4.25 & 4.57 & $\begin{array}{l}\bar{x}=4.35 \\
\mathrm{cV}=0.16\end{array}$ \\
\hline $\begin{array}{l}\text { Adoption of technology } \\
\text { and innovations of } \\
\text { products and processes } \\
\text { in the processing } \\
\text { industry }\end{array}$ & 3.84 & 3.61 & 3.13 & $\begin{array}{l}\bar{x}=3.47 \\
\mathrm{cv}=0.16\end{array}$ \\
\hline $\begin{array}{l}\text { Improvement of } \\
\text { farmers' income }\end{array}$ & 3.85 & 3.03 & 3.03 & $\begin{array}{c}\bar{x}=3.32 \\
\mathrm{cV}=0.27\end{array}$ \\
\hline $\begin{array}{c}\text { Stimulation of } \\
\text { production with } \\
\text { domestic and foreign } \\
\text { investment in non-EU } \\
\text { Mediterraneancoun- } \\
\text { tries }\end{array}$ & 3.60 & 4.25 & 3.57 & $\begin{array}{l}\bar{x}=3.75 \\
\mathrm{cV}=0.23\end{array}$ \\
\hline
\end{tabular}

Note: Values represent mean importance on a five-point scale from "not at all important" to "very important".

Other contributing factors are the stimulation of production with domestic and foreign investment in non-EU Mediterranean countries, the incorporation of technology and innovations of products and processes in the milling industry, and the improvement of farmers' income. In many producer countries, the implementation of structural and technological improvements through the introduction of product and process innovations at the olive oil processing stage proved to have a positive impact on production by boosting both the yield and the quality of the olive oil, while at the same time contributed to the reduction of the environmental contamination resulting from olive processing $[9,11]$.

\subsection{Expected Trends in the Global Demand for Olive Oil}

The growth in the global demand for olive oil witnessed in the past years is expected to persist and, in some cases, intensify in the upcoming years, with projected annual growth rates ranging between $2 \%$ and $10 \%$ across countries. Figure 3 shows the results obtained in regard to the magnitude of demand increase as well as its degree of impact on Spanish exports in each of the countries where olive oil consumption growth is expected. The overall means and coefficients of variation are mentioned on Figure 3, whereas the means by groups are presented in Table A2. 


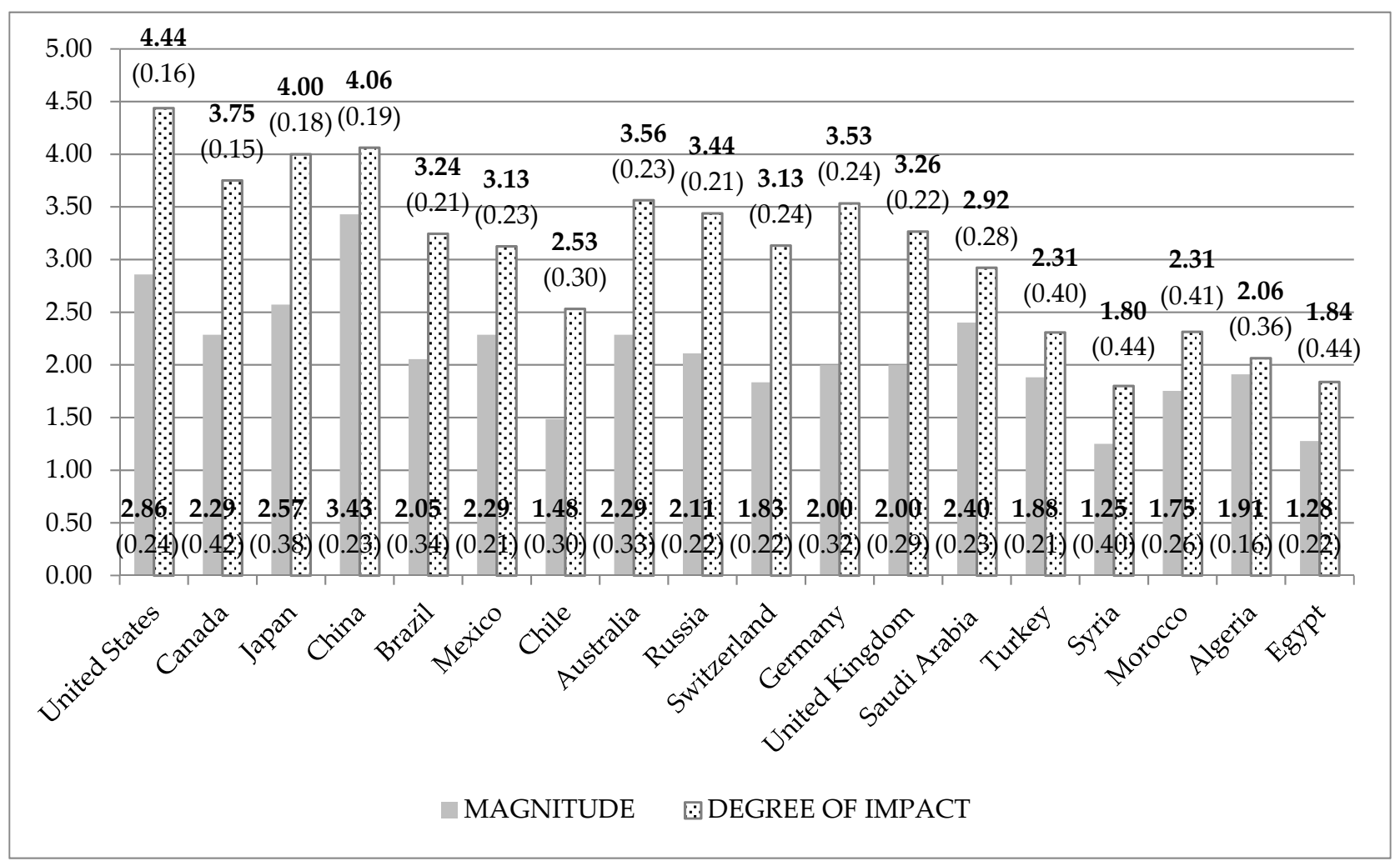

Figure 3. Magnitude of annual increase in world demand for olive oil and its degree of impact on Spanish exports (overall mean and coefficient of variation). Note: Values represent (a) mean annual growth on a four-point scale from "very moderate increase" to "very sharp increase" (figures down in the chart), and (b) mean impact on a five-point scale from "insignificant" to "very significant" (up in the chart). Coefficient of variation values are displayed in parentheses.

Overall, most of the growth is awaited in countries that have not been traditionally consumers, as the product's appeal is spreading, and its health and nutritional properties are valued by increasing numbers of consumers worldwide. This implies that the historical pattern of the Mediterranean predominance in olive oil consumption [67] will be further altered in the future.

The experts estimate that the highest increase rate in olive oil consumption in the coming years will likely be recorded in China, where consumers have recently developed a taste for olive oil and are manifesting a growing interest for the product. Data provided by the IOC [10] indicate that the country's purchases of olive oil have increased threefold in volume between 2008 and 2020. It is predicted that Chinese olive oil imports will continue to increase at a fairly high pace in the years to come, thus attracting domestic and international investors to this emerging market [65]. Therefore, special attention should be paid to the Chinese market that apparently holds a huge growth potential, mainly due to the size of the country's population, the changes in consumption habits resulting from rising living standards, and the opening of national economy to international trade. A number of olive oil companies are determined to take advantage of market potential in China. Some have built recently bottling plants in that country in order to increase sales of packaged olive oil [14]. The Chinese consumers, especially the more affluent, base their purchase decision on quality and brand. Therefore, it will be necessary to promote olive oil as a quality product in order to capture their interest. In any event, European olive oil companies will need more than a quality product to be able to conquer the Chinese mass market, especially with Australia as a serious export competitor in the top-quality segment. Extensive promotion actions including substantial public relations will be necessary to attract the attention of importers and to raise awareness on the benefits of Mediterranean olive oil in China. 
Unsurprisingly, the US also is expected to further expand its demand for olive oil, and will therefore continue to be the most relevant destination for olive oil exports in the upcoming years. As seen above, the US market is the world's third largest olive oil consumer in quantitative terms after Italy and Spain. With a consumption of 330,000 tons in 2019-2020, the country is already perceived as safe and profitable for exportation. This explains why important Spanish olive oil exporting groups have placed the US market at the heart of their internationalization strategies [14].

Japan, Canada, Australia, Brazil, and Russia are other potentially attractive markets to the Spanish olive oil marketers. These countries have been occupying an increasing share in the world consumption of olive oil in the recent years and hold a strong potential for consumption growth in the future. Within the group of Mediterranean consumers, consumption growth in Algeria, Turkey and Morocco will likely experience a slowdown, if compared with the annual growth rate recorded in the previous years. The demand for olive oil in Germany and in the UK is likely to continue increasing at approximatively the same rate as it did in the past years.

Regarding the degree of impact of the aforementioned future increases in demand on the Spanish exports, the experts estimate that a significant impact is to be expected from the consumption growth in the US, China, and Japan. Taking into consideration the population size and the strong magnitude of increase predicted in these countries on one hand, and the fact that Spain is an important supplier to these markets on the other hand, it is safe to assume that such demand expansion will spur the Spanish exports. Meanwhile, the relatively more moderate growth in demand expected in countries such as Canada, Australia, Russia, and Germany, will probably have a limited impact on the Spanish exports.

According to the expert panel, the future increases in the global demand will likely be induced by the growing interest of consumers for olive oil and their increasing awareness of its nutritional and dietary properties. Demand will also be prompted by the shift in consumption habits towards healthier and more natural products, and to a lesser degree by preference towards more differentiated products such as organic olive oil and oils with indications of origin (Table 4).

Interestingly, there is a broad agreement that further promotional campaigns in nontraditional markets - like those conducted by the IOC from the mid-1980s to the early 2000s, which have been efficient in expanding olive oil consumption in emerging markets, can play a major role in attracting new consumers. In addition, the increasing availability of olive oil in non-traditional consumer markets is expected to boost consumption volumes, given the fact that product availability has long been considered by marketers as a central feature in triggering purchase [68].

Likewise, economic factors such as the increase in per capita income in emerging consumer countries and the decreasing impact of the economic crisis will be key determinants of the future evolution of the olive oil consumption, as the rise in disposable incomes encourages the consumers to try new products and incentivize greater expenditures on high-value food products. Meanwhile, the reduction in the volatility of international prices, even being quite relevant, is likely to have a lower impact on the evolution of the demand, when compared with other factors. 
Table 4. Conditioning factors of the future increase in the global demand for olive oil.

\begin{tabular}{|c|c|c|c|c|}
\hline & $\begin{array}{l}\text { Industry Experts and } \\
\text { Representatives of } \\
\text { Business Associations }\end{array}$ & $\begin{array}{c}\text { Representatives of } \\
\text { Public Administration }\end{array}$ & $\begin{array}{c}\text { Representatives of } \\
\text { Academia }\end{array}$ & $\begin{array}{l}\text { Overall Mean }(\bar{x}) \text { and } \\
\text { Coefficient of } \\
\text { Variation (cv) }\end{array}$ \\
\hline $\begin{array}{l}\text { Increase in per capita } \\
\text { income in emerging } \\
\text { consumer countries }\end{array}$ & 3.83 & 4.25 & 4.00 & $\begin{array}{c}\bar{x}=4.00 \\
\mathrm{cV}=0.18\end{array}$ \\
\hline $\begin{array}{l}\text { Increasing availability } \\
\text { of olive oil in } \\
\text { non-traditional markets }\end{array}$ & 4.17 & 4.00 & 3.57 & $\begin{array}{c}\bar{x}=3.88 \\
\mathrm{cV}=0.18\end{array}$ \\
\hline $\begin{array}{l}\text { Promotional campaigns } \\
\text { to consumers in } \\
\text { non-traditional markets }\end{array}$ & 4.33 & 4.75 & 4.29 & $\begin{array}{c}\bar{x}=4.41 \\
\mathrm{cV}=0.14\end{array}$ \\
\hline $\begin{array}{l}\text { Trend towards more } \\
\text { differentiated products, } \\
\text { including organic olive } \\
\text { oil and olive oil with } \\
\text { geographical } \\
\text { indications and } \\
\text { denominations of } \\
\text { origin }\end{array}$ & 3.50 & 3.08 & 3.62 & $\begin{array}{c}\bar{x}=3.45 \\
\mathrm{cV}=0.13\end{array}$ \\
\hline $\begin{array}{l}\text { Increased consumer } \\
\text { awareness of the } \\
\text { nutritional and dietary } \\
\text { properties of olive oil }\end{array}$ & 4.00 & 4.50 & 5.00 & $\begin{array}{c}\bar{x}=4.53 \\
\mathrm{cV}=0.18\end{array}$ \\
\hline $\begin{array}{l}\text { Shift in consumption } \\
\text { habits towards } \\
\text { healthier and natural } \\
\text { products }\end{array}$ & 4.50 & 4.25 & 4.14 & $\begin{array}{c}\bar{x}=4.29 \\
\mathrm{cV}=0.14\end{array}$ \\
\hline $\begin{array}{l}\text { Decreasing impact of } \\
\text { the economic crisis }\end{array}$ & 3.50 & 4.00 & 4.00 & $\begin{array}{c}\bar{x}=3.82 \\
\mathrm{cV}=0.19\end{array}$ \\
\hline $\begin{array}{l}\text { Reduction in the } \\
\text { volatility of } \\
\text { international prices }\end{array}$ & 3.83 & 3.00 & 3.14 & $\begin{array}{l}\bar{x}=3.35 \\
\mathrm{cv}=0.23\end{array}$ \\
\hline
\end{tabular}

Note: Values represent mean importance on a five-point scale from "not at all important" to "very important".

\subsection{Major Future Challenges in the International Trade of Olive Oil}

Among the challenges that will be facing the international trade of olive oil in the upcoming years, the experts granted the highest degree of importance to the demand increase in non-traditional consumer countries (Table 5). This can be explained by the additional effort needed to promote olive oil in countries where its consumption is not deeply rooted in the domestic culture, and adapt the offer according to the characteristics of the targeted market and the preferences of the potential consumers. On the contrary, increasing consumption in traditional producer countries is deemed comparatively less likely as these markets are considered mature and relatively saturated.

The experts also highlighted the importance of the harmonization of international quality standards, along with the clarification of the denominations of the different olive oils for their better understanding by consumers. Indeed, non-traditional consumers are often unable to distinguish the different olive oil grades and varieties, which leads to deficient perceptions of the quality and specificity of each product. This situation calls for clear labelling that indicates the quality attributes, country, terroir and designation of origin, and highlights the need for educating the consumers on the differences between olive oil categories. 
Table 5. Major challenges in the international trade of olive oil.

\begin{tabular}{|c|c|c|c|c|}
\hline & $\begin{array}{l}\text { Industry Experts and } \\
\text { Representatives of } \\
\text { Business Associations }\end{array}$ & $\begin{array}{c}\text { Representatives of } \\
\text { Public Administration }\end{array}$ & $\begin{array}{l}\text { Representatives } \\
\text { of Academia }\end{array}$ & $\begin{array}{l}\text { Overall Mean }(\bar{x}) \\
\text { and Coefficient of } \\
\text { Variation (cv) }\end{array}$ \\
\hline Trade liberalization & 4.00 & 4.00 & 3.43 & $\begin{array}{c}\bar{x}=3.76 \\
\mathrm{cV}=0.22\end{array}$ \\
\hline $\begin{array}{l}\text { Opening of new quotas } \\
\text { for southern } \\
\text { Mediterranean } \\
\text { countries }\end{array}$ & 3.50 & 3.25 & 3.43 & $\begin{array}{c}\bar{x}=3.41 \\
\mathrm{cV}=0.21\end{array}$ \\
\hline $\begin{array}{l}\text { Implementing trade } \\
\text { facilitation measures }\end{array}$ & 4.17 & 4.00 & 4.00 & $\begin{array}{l}\bar{x}=4.06 \\
\mathrm{cV}=0.20\end{array}$ \\
\hline $\begin{array}{c}\text { Facilitation of } \\
\text { investments in foreign } \\
\text { countries }\end{array}$ & 3.33 & 4.00 & 4.00 & $\begin{array}{l}\bar{x}=3.75 \\
\mathrm{cv}=0.25\end{array}$ \\
\hline $\begin{array}{l}\text { Fluctuations in } \\
\text { currency exchange } \\
\text { markets }\end{array}$ & 3.67 & 3.30 & 3.49 & $\begin{array}{l}\bar{x}=3.51 \\
\mathrm{cV}=0.16\end{array}$ \\
\hline $\begin{array}{c}\text { Unsatisfactory } \\
\text { harmonization of } \\
\text { international quality } \\
\text { standards }\end{array}$ & 4.83 & 4.50 & 4.43 & $\begin{array}{c}\bar{x}=4.59 \\
\mathrm{cV}=0.13\end{array}$ \\
\hline $\begin{array}{l}\text { Private standards } \\
\text { established by } \\
\text { distributors in } \\
\text { destination }\end{array}$ & 3.33 & 4.00 & 4.00 & $\begin{array}{l}\bar{x}=3.73 \\
\mathrm{cV}=0.29\end{array}$ \\
\hline $\begin{array}{l}\text { Demand increase in } \\
\text { non-traditional } \\
\text { consumer countries }\end{array}$ & 4.50 & 4.33 & 4.86 & $\begin{array}{c}\bar{x}=4.63 \\
\mathrm{cv}=0.13\end{array}$ \\
\hline $\begin{array}{c}\text { Demand increase in } \\
\text { traditional producer } \\
\text { countries }\end{array}$ & 3.50 & 3.50 & 4.20 & $\begin{array}{c}\bar{x}=3.73 \\
\mathrm{cv}=0.21\end{array}$ \\
\hline $\begin{array}{l}\text { Clarification of olive oil } \\
\text { denominations for their } \\
\text { better understanding } \\
\text { by consumers }\end{array}$ & 4.33 & 3.50 & 4.43 & $\begin{array}{l}\bar{x}=4.18 \\
\mathrm{cV}=0.21\end{array}$ \\
\hline $\begin{array}{c}\text { Poor product } \\
\text { positioning and low } \\
\text { level of differentiation }\end{array}$ & 3.83 & 3.67 & 4.17 & $\begin{array}{l}\bar{x}=3.93 \\
\mathrm{cv}=0.18\end{array}$ \\
\hline $\begin{array}{l}\text { Competitive pressure } \\
\text { from substitute oils }\end{array}$ & 4.00 & 3.04 & 3.20 & $\begin{array}{c}\bar{x}=3.44 \\
\mathrm{cv}=0.23\end{array}$ \\
\hline $\begin{array}{l}\text { Stability and reliability } \\
\text { of supplies }\end{array}$ & 4.33 & 3.67 & 4.00 & $\begin{array}{l}\bar{x}=4.06 \\
\mathrm{cV}=0.19\end{array}$ \\
\hline $\begin{array}{c}\text { Transparency in the } \\
\text { international value } \\
\text { chain }\end{array}$ & 4.17 & 3.00 & 4.29 & $\begin{array}{l}\bar{x}=4.00 \\
\mathrm{cv}=0.22\end{array}$ \\
\hline $\begin{array}{l}\text { International price } \\
\text { volatility }\end{array}$ & 4.00 & 3.25 & 3.67 & $\begin{array}{l}\bar{x}=3.69 \\
\mathrm{cV}=0.19\end{array}$ \\
\hline $\begin{array}{l}\text { Lack of an official and } \\
\text { universal price } \\
\text { reference }\end{array}$ & 3.17 & 2.50 & 3.14 & $\begin{array}{l}\bar{x}=3.00 \\
\mathrm{cV}=0.20\end{array}$ \\
\hline
\end{tabular}

Note: Values represent mean importance on a five-point scale from "not at all important" to "very important". 
Interestingly, major challenges that will be posed to the sector refer to trade facilitation measures (more transparent, predictable, and simplified cross-border procedures), tariff liberalization, and the facilitation of international investments. In the case of Russia, for instance, a simplification of import procedures could help to promoting more actively olive oil from the EU into the Russian market [69].

Future challenges also include the stability and reliability of supplies, the transparency in the international olive oil value chain, as well as the weak product positioning and low level of product differentiation. The latter illustrates the need for stronger and more focused marketing strategies, especially since olive oil market is expected to be more and more segmented on the basis of quality differences in the future. Besides, the fluctuations in currency exchange markets and the volatility of international prices are both considered as potential hindering factors for the internationalization of the sector. Indeed, a number of respondents highlighted the need for establishing market management mechanisms at the whole sector level in order to prevent price fluctuations. Such measure would allow strengthening consumers' loyalty and mitigating the impact of price swings on demand in export markets.

Furthermore, experts are not extremely worried about the competitive pressure from substitute oils in the international market in the upcoming years. This is probably due to the increasing awareness among consumers that olive and other edible oils are different in terms of characteristics, nutritional values, and types of use, which makes the substitution relatively limited. However, the price differential in favor of other vegetable oils is often a powerful factor in purchase decision, especially in the case of extremely price-sensitive consumers.

Likewise, the opening of new quotas for southern Mediterranean countries is unlikely to be a major concern for the major exporters. The larger quotas of olive oil imports granted to Tunisia and Morocco are not seen as a threat to Spain and Italy, but rather a positive option in times of reduced production. For EU operators, it is less worrisome that EU imports olive oil from these countries than if it is imported by other countries [14]. Lastly, the lack of an official and universal price reference in the international olive oil market is also perceived as a challenge though in a lesser extent. The virtual nonexistence of a clearly defined and unified world-reference price for olive oil makes it difficult to compare the efficiency of different olive oil markets and their degree of competition and spatial and temporal integration, thus hampering the due transparency and predictability of those markets.

\section{Discussion}

The Delphi survey carried out reflects the collaborative intelligence of a group of highly qualified experts who represented vastly different organizations, from most relevant olive oil companies and business organizations to public administrations and academic research. The elicited estimates cover the whole spectrum of relevant countries, add accuracy and consistency to the available market knowledge in the olive oil sector, and therefore help managers when drafting new strategies or challenging those already in place. The study contributes to solve one of the most pressing concerns of the olive oil industry, namely the need to dispose of informative projections allowing to deal with increased market uncertainties, and underpin the stakeholders' strategic goals towards better regulations, investment decisions, and value propositions in key growth areas.

Our results with regard to supply prospects for the EU are largely consistent with those reported in the latest outlook for the EU agricultural markets to 2030 [5]. According to the EU outlook, the EU olive oil production is expected to grow by $1.3 \%$ per year by 2030, with annual growth rates of 2\% in Spain, $0.9 \%$ in Italy, $0.4 \%$ in Greece, and 3.8\% in Portugal; these values are vastly in line with the estimates obtained in our study covering the period 2017-2025. It should be noted that EU projections assume normal agronomic and climate conditions, a continuation of current agricultural and trade policies and not the ones under discussion such as the post-2020 Common Agricultural Policy reform or 
the European Green Deal and take into consideration a series of market uncertainties particularly fluctuations in the macroeconomic environment and the impact of COVID-19 pandemic. The EU prospects also indicate that this growth will be driven by increasing yields ( $0.5 \%$ per year on average), new plantations, improving agronomic conditions of trees, and further investment in intensive and super-intensive production systems. However, production expansion will face challenges created by fluctuations in yields and prices, damage to olive groves caused by pests and diseases in certain EU regions, the small farm size, and the high average age of farmers especially in Italy and Greece [5].

From the demand viewpoint, our results for the EU also are in line with the EU outlook where total consumption is projected to grow solely by $0.2 \%$ per year by 2030 (the outlook does not quantify future growth rates in olive oil consumption by country), this growth being concentrated in the EU non-producing countries, which by 2030 could account for $26 \%$ of EU consumption compared to $20 \%$ in 2019 [5]. Globally, demand boost can be achieved by targeting the continuously expanding consumer groups interested in adopting healthier diets, through promotional campaigns that emphasize the organoleptic, nutritional, and dietary properties of olive oil. Demand also could be enhanced through integrating olive oil into modern lifestyles (e.g., foodservice, vegetarianism, slow food), and valorizing the heterogeneity of perceptions of different consumer segments in relation to specific characteristics of olive oil including geographical origin, certification, and processing technology (artisanal vs. industrial) [70-72].

At an international level, the weak agreement on quality standards generates tensions in trade between countries [8], since the standards provided by the IOC are often criticized for being unenforced and too broad by non-IOC countries such as Australia and the US. Another relevant challenge relates to trade facilitation referring to measures that contribute to simplify and harmonize the export and import processes, including data exchange about shipments, simplification, and modernization of trade documents and procedures, and effective cooperation between trade authorities [73]. Trade facilitation through easing time and bureaucratic burdens often results in lower overall trade costs, and greater expansion and diversification of exchanges and investments [73,74].

Moreover, the fluctuations in currency exchange rates and the volatility of international prices can hamper the internationalization of olive oil. There have been recurring boom and bust cycles in the olive oil producer prices that have hit the sector and have been high on policy agendas. Producer prices vary according to supply and demand, but also are influenced by market speculative movements, currency movements (a stronger currency tends to decrease exports and increase imports, thereby reducing the international competitiveness of domestic production), information asymmetries, and policy interventions (e.g., EU threshold prices for private storage granted in case of difficult market situations). Power relations within the supply chain are crucial in setting producer prices, probably even more than the quality of the product. At downstream level, the fact that price elasticity of demand for the olive oil is relatively higher for the upper quality segments (virgin vs. non-virgin olive oils) and in the non-traditional markets where olive oil consumption is not deeply rooted $[6,75]$, implies that price swings can impact instantly and largely the demand in these product categories and countries.

One point must also be mentioned in relation to the COVID-19 crisis that arrived in 2020. As in other food markets, the overall impact of the COVID-19 outbreak on the olive oil market has remained somewhat limited during the early months thanks to the quick policy measures introduced to contain the pandemic [5], and the relatively inelastic demand of food products [76,77]. In the initial period of this major shock, total retail sales and prices of olive oil increased in many countries, in particular in the EU's main producing countries, despite the reduction in demand from restaurants and foodservice, which represent about $15 \%$ of the total olive oil purchases in the EU [78]. At the same time, the confinement measures have led to a vast increase of demand for e-commerce including olive oil, in addition to greater demand for locally produced food and short supply chains $[78,79]$. Moreover, although the income losses and concerns about future 
incomes prompted changes in consumers' spending patterns, a significant proportion of consumers have shifted to buying healthier, more sustainable food [80]. It seems that this behavior by many consumers in many countries will be lasting in the post-pandemic world $[79,81]$. This likely evolution might arguably represent an opportunity for olive oil producers and traders to expand their markets, as olive oil is quite well positioned to respond to consumer concerns in terms of health and environment benefits.

In the longer term, the impacts of COVID-19 on the agricultural markets including olive oil are still uncertain and will depend on potential societal change (values, lifestyles) in response to the epidemic and the economic recovery pathways, which, in turn, depend on the evolution of the disease and movement restrictions, political developments, and other micro and macroeconomic factors [5,76,82]. It is still unclear in which areas of the food system the pandemic shock will lead to profound structural transformations or a marginal adaptation to a new normal. As in other agri-food sectors, the COVID-19 crisis has revealed the vulnerabilities of the olive oil supply chain and the importance of fostering its resilience to respond to global shocks. It also offers the opportunity for the olive oil industry reform to become stronger and more robust through increasing its focus on quality, sustainability, and collaboration among sector stakeholders.

In a relatively quick recovery scenario, global demand for olive oil could increase significantly leading to an increase in global exports. However, for the time being, data from IOC [10] for the crop year 2020-2021 indicate that global olive oil exports and imports are expected to decrease by $18 \%$ and $17 \%$ in volume, respectively, with respect to the previous crop year 2019-2020 despite similar levels of global production and consumption in both years, probably in part due to disruptions from the coronavirus epidemic worldwide. Therefore, dispelling uncertainties regarding international market access due to COVID-19 will also be critical for business continuity and future growth in this industry. Note that the major effects on global trade precipitated by COVID-19 has resulted from government restrictions on international personal and economic activity [83]. It is well-known that trade constraints, risks, and uncertainties in international markets affect global food prices and often increase their volatility [76,84]. Lessons from past crises have shown that avoidance of trade-restrictive policies is trade enhancing and can be as effective to protect consumers and farm incomes as direct support measures [85]. Likewise, uncooperative trade policy actions expressed through escalated trade restrictive measures are to be avoided, as they entail a multiplier effect that could magnify the disruptions in global markets caused by the COVID-19 shock [86].

\section{Conclusions and Future Research}

Developments in supply and demand are key factors for the future of the global market for olive oil. This study explores the expected trends and directions in the global supply and demand that will likely take place in the olive oil sector in the years to come. It also identifies the future challenges that will be posed to the actors of the sector as well as the main factors that will shape the international environment in which they will be operating. With scant comprehensive studies on the future of supply, demand, and market challenges for olive oil, this study provides unique insights to policymakers and businesses in their decision-making and strategic planning. Still, as any projection, the results from the Delphi survey carried out represent one out of possible trajectories that are likely to occur around the consensus view.

The findings of our research reveal a broad consensus that many of the developments seen in the global olive oil market during the recent period will likely be maintained or even accelerated in the upcoming years. Overall trends suggest a future scenario marked by growing globalization of the olive oil sector as its international expansion increases. On the supply side, substantial increases in production will be observed in the countries that have traditionally been non-producers, whereas a relatively slower growth is expected in the EU producer countries, whose focus is increasingly placed on the quality and sustainability rather than the quantity of olive oil produced. The foreseen growth in supply 
will be the result of higher productivity, especially in the modern plantations developed in traditional and non-traditional producing countries, along with the continuous adoption of technological innovations in the milling industry.

On the demand side, our results indicate that the global demand for olive oil is expected to continue increasing and diversifying geographically, prompted by rising incomes and concerns about nutrition, health, and the environment. Most of the growth will take place in non-traditional markets, especially China, the US, Japan, and Russia, whose impact on the Spanish exports might be the greatest. The low per capita consumption together with a low household penetration rate of olive oil in non-producing countries suggest that there is room for expanding demand both by reaching a larger number of consumers, and by increasing the quality and frequency of purchases performed by existing consumers. Given the size of these markets, even a slight increase in these two parameters can significantly impact their total consumption levels.

On the international trade side, the olive industry will have to face a series of challenges among which stand out the entry in new markets to increase demand where olive oil is not traditionally consumed, product promotion worldwide, improvement of the harmonization of international quality standards, and the enforcement of trade facilitation to simplify international trading procedures. World olive oil price volatility also is a relevant issue where there is a need for further analyses relying on sound approaches emphasizing the economic processes underlying the formation of prices, and incorporating the main drivers of the perceived dynamics and the effective causes behind this volatility. Moreover, the COVID-19 crisis will most likely induce changes and adaptations in the olive oil supply chain, while at the same time it has revealed the importance of informative foresight and anticipation in raising the sector's preparedness in the face of disruptions caused by unforeseen shocks.

In order to efficiently respond to future challenges and take advantage from market opportunities, the olive oil supply chain will need to be globally more sustainable, robust, and resilient. Accelerating the transition towards more sustainability and resilience will bring environmental, health, and social benefits to consumers. It also can provide economic gains to olive oil enterprises and help the recovery from the COVID-19. The process should cover every stage in the olive oil supply chain from production to consumption and trade.

This study leaves several avenues open for further research. In future research, it would be interesting to carry out this analysis in more countries interested in the olive oil industry, thereby allowing comparative analyses of views and perspectives. It is also appropriate for further research to use the Delphi technique to (i) broaden our understanding and anticipate the impacts of factors that inexorably will shape the olive oil market in the future including sustainability, digitalization, innovation, promotion, and crisis management, and (ii) develop future scenarios for aspects that might hinder the development of the global olive oil sector, such as the uncertainties surrounding the post-COVID-19 pandemic recovery, the competitive pressure from the other types of edible oils, potential restrictive international regulations, and adverse shocks and damages from climate change, pests and disease, and water scarcity. This would enable enacting and implementing new policies, business models, alliances, and areas of collaboration between stakeholders to deal with these complex challenges.

From a methodological viewpoint, it is advisable to use more international panels with experts from different countries, including the new-world olive oil players. This would provide a broader vision of the sector by incorporating a wider range of distant locational and cultural perspectives, even though such approach undoubtedly requires ambitious efforts and an international network to ensure the cooperation of the experts. In addition, to take it one step further, real-time Delphi schemes can be applied to make the process more interactive, engaging, and rapid $[87,88]$. Another option would be to carry out internetbased Delphi, taking advantage of the technological platforms in enhancing a classic Delphi research process through facilitating discussion among participants separated by place and time $[53,89]$. In addition, it is worthwhile to explore the potential usefulness of combining 
Delphi with other techniques, using Delphi as a means of eliciting group-based estimates for integration with other futures methodologies (e.g., cross-impact analysis [90], scenario studies [91]) as well as, for instance, for establishing exogenous variables and parameters for statistical or econometric models $[92,93]$.

Author Contributions: Conceptualization, S.M.; methodology, S.M. and M.B.; formal analysis, S.M. and M.B.; writing - original draft preparation, S.M. and M.B. All authors have read and agreed to the published version of the manuscript.

Funding: This research was performed in the framework of the project 202010E136 "New Approaches for Generating Innovative, Sustainable and Resilient Business Models in the Agri-Food Sector" funded by the Spanish National Research Council (CSIC).

Institutional Review Board Statement: Not applicable.

Informed Consent Statement: Not applicable.

Acknowledgments: The authors acknowledge support to cover publication fees by the CSIC Open Access Publication Support Initiative through its Unit of Information Resources for Research (URICI). The authors also thank all the experts who participated in the Delphi panel for their valuable input for this study.

Conflicts of Interest: The authors declare no conflict of interest.

\section{Appendix A}

Table A1. Magnitude of the annual increase in the olive oil supply and its degree of impact on Spanish exports.

\begin{tabular}{|c|c|c|c|c|c|c|c|c|}
\hline \multirow[b]{2}{*}{ Country } & \multicolumn{2}{|c|}{$\begin{array}{l}\text { Industry Experts and } \\
\text { Representatives of } \\
\text { Business Associations }\end{array}$} & \multicolumn{2}{|c|}{$\begin{array}{l}\text { Representatives of } \\
\text { Public Administration }\end{array}$} & \multicolumn{2}{|c|}{$\begin{array}{l}\text { Representatives } \\
\text { of Academia }\end{array}$} & \multicolumn{2}{|c|}{$\begin{array}{c}\text { Overall Mean }(\bar{x}) \text { and } \\
\text { Coefficient of Variation (cv) }\end{array}$} \\
\hline & Magnitude & $\begin{array}{c}\text { Degree } \\
\text { of Impact }\end{array}$ & Magnitude & $\begin{array}{l}\text { Degree } \\
\text { of Impact }\end{array}$ & Magnitude & $\begin{array}{c}\text { Degree } \\
\text { of Impact }\end{array}$ & Magnitude & $\begin{array}{c}\text { Degree } \\
\text { of Impact }\end{array}$ \\
\hline Spain & 2.00 & 4.00 & 2.00 & 3.67 & 2.25 & 4.40 & $\begin{array}{l}\bar{x}=2.13 \\
\mathrm{cv}=0.30\end{array}$ & $\begin{aligned} \bar{x} & =4.07 \\
\mathrm{cv} & =0.20\end{aligned}$ \\
\hline Italy & 0.83 & 3.30 & 1.33 & 1.74 & 1.64 & 2.74 & $\begin{array}{l}\bar{x}=1.38 \\
\mathrm{cv}=0.49\end{array}$ & $\begin{aligned} \bar{x} & =2.67 \\
\mathrm{cv} & =0.43\end{aligned}$ \\
\hline Greece & 1.00 & 2.75 & 1.00 & 1.63 & 1.67 & 2.36 & $\begin{aligned} \bar{x} & =1.29 \\
\mathrm{cv} & =0.50\end{aligned}$ & $\begin{aligned} \bar{x} & =2.27 \\
\mathrm{cv} & =0.48\end{aligned}$ \\
\hline Portugal & 1.50 & 3.33 & 2.50 & 3.07 & 3.00 & 3.19 & $\begin{array}{l}\bar{x}=2.43 \\
\mathrm{cv}=0.40\end{array}$ & $\begin{aligned} \bar{x} & =3.21 \\
\mathrm{cv} & =0.22\end{aligned}$ \\
\hline Turkey & 2.50 & 3.20 & 2.50 & 2.93 & 3.00 & 3.44 & $\begin{array}{l}\bar{x}=2.67 \\
\mathrm{cv}=0.19\end{array}$ & $\begin{array}{c}\bar{x}=3.22 \\
\mathrm{cV}=0.27\end{array}$ \\
\hline Tunisia & 2.67 & 3.40 & 2.33 & 3.50 & 3.00 & 3.44 & $\begin{aligned} \bar{x} & =2.75 \\
\mathrm{cv} & =0.31\end{aligned}$ & $\begin{aligned} \bar{x} & =3.47 \\
\mathrm{cv} & =0.34\end{aligned}$ \\
\hline Syria & 2.00 & 2.00 & 1.25 & 1.54 & 1.50 & 1.67 & $\begin{aligned} \bar{x} & =1.50 \\
\mathrm{cv} & =0.33\end{aligned}$ & $\begin{array}{c}\bar{x}=1.72 \\
\mathrm{cv}=0.48\end{array}$ \\
\hline Morocco & 3.00 & 3.28 & 3.00 & 3.44 & 3.67 & 3.22 & $\begin{aligned} \bar{x} & =3.29 \\
\mathrm{cv} & =0.23\end{aligned}$ & $\begin{aligned} \bar{x} & =3.29 \\
\mathrm{cv} & =0.27\end{aligned}$ \\
\hline Algeria & 2.50 & 2.50 & 2.50 & 2.50 & 2.50 & 2.80 & $\begin{array}{l}\bar{x}=2.50 \\
\mathrm{cV}=0.23\end{array}$ & $\begin{aligned} \bar{x} & =2.62 \\
\mathrm{cv} & =0.25\end{aligned}$ \\
\hline Egypt & 1.50 & 2.38 & 1.33 & 1.97 & 1.75 & 2.48 & $\begin{array}{l}\bar{x}=1.60 \\
\mathrm{cv}=0.32\end{array}$ & $\begin{array}{l}\bar{x}=2.30 \\
\mathrm{cv}=0.31\end{array}$ \\
\hline Israel & 1.25 & 1.63 & 1.00 & 1.75 & 1.50 & 1.92 & $\begin{aligned} \bar{x} & =1.25 \\
\mathrm{cv} & =0.40\end{aligned}$ & $\begin{aligned} \bar{x} & =1.79 \\
\mathrm{cv} & =0.49\end{aligned}$ \\
\hline Jordan & 1.50 & 1.63 & 1.33 & 1.90 & 1.50 & 2.58 & $\begin{aligned} \bar{x} & =1.45 \\
\mathrm{cv} & =0.20\end{aligned}$ & $\begin{aligned} \bar{x} & =2.11 \\
\mathrm{cv} & =0.39\end{aligned}$ \\
\hline Iran & 3.00 & 2.50 & 2.00 & 1.97 & 2.00 & 2.55 & $\begin{array}{l}\bar{x}=2.20 \\
\mathrm{cV}=0.20\end{array}$ & $\begin{array}{c}\bar{x}=2.38 \\
\mathrm{cV}=0.41\end{array}$ \\
\hline
\end{tabular}


Table A1. Cont.

\begin{tabular}{|c|c|c|c|c|c|c|c|c|}
\hline \multirow[b]{2}{*}{ Country } & \multicolumn{2}{|c|}{$\begin{array}{l}\text { Industry Experts and } \\
\text { Representatives of } \\
\text { Business Associations }\end{array}$} & \multicolumn{2}{|c|}{$\begin{array}{c}\text { Representatives of } \\
\text { Public Administration }\end{array}$} & \multicolumn{2}{|c|}{$\begin{array}{l}\text { Representatives } \\
\text { of Academia }\end{array}$} & \multicolumn{2}{|c|}{$\begin{array}{c}\text { Overall Mean }(\bar{x}) \text { and } \\
\text { Coefficient of Variation (cv) }\end{array}$} \\
\hline & Magnitude & $\begin{array}{c}\text { Degree } \\
\text { of Impact }\end{array}$ & Magnitude & $\begin{array}{c}\text { Degree } \\
\text { of Impact }\end{array}$ & Magnitude & $\begin{array}{c}\text { Degree } \\
\text { of Impact }\end{array}$ & Magnitude & $\begin{array}{c}\text { Degree } \\
\text { of Impact }\end{array}$ \\
\hline Argenti-na & 2.35 & 3.00 & 2.13 & 2.75 & 2.73 & 2.83 & $\begin{array}{c}\bar{x}=2.52 \\
\mathrm{cv}=0.22\end{array}$ & $\begin{aligned} \bar{x} & =2.86 \\
\mathrm{cV} & =0.30\end{aligned}$ \\
\hline Australia & 2.33 & 3.60 & 2.33 & 2.67 & 3.00 & 3.17 & $\begin{aligned} \bar{x} & =2.69 \\
\mathrm{cv} & =0.28\end{aligned}$ & $\begin{aligned} \bar{x} & =3.21 \\
\mathrm{cv} & =0.35\end{aligned}$ \\
\hline Chile & 1.00 & 2.25 & 2.50 & 2.44 & 3.00 & 2.93 & $\begin{aligned} \bar{x} & =2.50 \\
\mathrm{cv} & =0.33\end{aligned}$ & $\begin{aligned} \bar{x} & =2.62 \\
\mathrm{cv} & =0.34\end{aligned}$ \\
\hline United States & 3.00 & 3.20 & 2.00 & 2.75 & 3.50 & 2.80 & $\begin{aligned} \bar{x} & =2.83 \\
\mathrm{cv} & =0.35\end{aligned}$ & $\begin{aligned} \bar{x} & =2.93 \\
\mathrm{cv} & =0.28\end{aligned}$ \\
\hline China & 4.00 & 3.40 & 3.50 & 2.94 & 4.00 & 3.52 & $\begin{array}{c}\bar{x}=3.86 \\
\mathrm{cV}=0.10\end{array}$ & $\begin{array}{c}\bar{x}=3.34 \\
\mathrm{cV}=0.25\end{array}$ \\
\hline South Africa & 2.00 & 2.88 & 2.00 & 1.94 & 2.33 & 2.43 & $\begin{array}{c}\bar{x}=2.17 \\
\mathrm{cV}=0.19\end{array}$ & $\begin{array}{c}\bar{x}=2.45 \\
\mathrm{cV}=0.32\end{array}$ \\
\hline
\end{tabular}

Note: Values represent mean annual growth on a four-point scale from "very moderate increase" to "very sharp increase", and mean impact on a five-point scale from "insignificant" to "very significant".

Table A2. Magnitude of the annual increase in the demand for olive oil and its degree of impact on Spanish exports.

\begin{tabular}{|c|c|c|c|c|c|c|c|c|}
\hline \multirow[b]{2}{*}{ Country } & \multicolumn{2}{|c|}{$\begin{array}{l}\text { Industry Experts and } \\
\text { Representatives of } \\
\text { Business Associations }\end{array}$} & \multicolumn{2}{|c|}{$\begin{array}{l}\text { Representatives of the } \\
\text { Public Administration }\end{array}$} & \multicolumn{2}{|c|}{$\begin{array}{l}\text { Representatives } \\
\text { of Academia }\end{array}$} & \multicolumn{2}{|c|}{$\begin{array}{c}\text { Overall Mean }(\bar{x}) \text { and } \\
\text { Coefficient of Variation (cv) }\end{array}$} \\
\hline & Magnitude & $\begin{array}{l}\text { Degree } \\
\text { of Impact }\end{array}$ & Magnitude & $\begin{array}{c}\text { Degree } \\
\text { of Impact }\end{array}$ & Magnitude & $\begin{array}{c}\text { Degree } \\
\text { of Impact }\end{array}$ & Magnitude & $\begin{array}{c}\text { Degree } \\
\text { of Impact }\end{array}$ \\
\hline United States & 2.50 & 4.67 & 2.50 & 4.00 & 3.33 & 4.50 & $\begin{array}{c}\bar{x}=2.86 \\
\mathrm{cv}=0.24\end{array}$ & $\begin{array}{l}\bar{x}=4.44 \\
\mathrm{cV}=0.16\end{array}$ \\
\hline Canada & 2.00 & 3.50 & 1.50 & 4.00 & 3.00 & 3.83 & $\begin{aligned} \bar{x} & =2.29 \\
\mathrm{cv} & =0.42\end{aligned}$ & $\begin{array}{l}\bar{x}=3.75 \\
\mathrm{cv}=0.15\end{array}$ \\
\hline Japan & 2.00 & 3.67 & 2.50 & 4.00 & 3.00 & 4.33 & $\begin{array}{c}\bar{x}=2.57 \\
\mathrm{cv}=0.38\end{array}$ & $\begin{aligned} \bar{x} & =4.00 \\
\mathrm{cv} & =0.18\end{aligned}$ \\
\hline China & 4.00 & 3.83 & 2.50 & 4.00 & 3.67 & 4.33 & $\begin{aligned} \bar{x} & =3.43 \\
\mathrm{cv} & =0.23\end{aligned}$ & $\begin{aligned} \bar{x} & =4.06 \\
\mathrm{cv} & =0.19\end{aligned}$ \\
\hline Brazil & 2.22 & 3.19 & 1.78 & 3.07 & 2.10 & 3.39 & $\begin{aligned} \bar{x} & =2.05 \\
\mathrm{cv} & =0.34\end{aligned}$ & $\begin{array}{l}\bar{x}=3.24 \\
\mathrm{cv}=0.21\end{array}$ \\
\hline Mexico & 2.50 & 3.33 & 2.00 & 2.75 & 2.33 & 3.17 & $\begin{aligned} \bar{x} & =2.29 \\
\mathrm{cv} & =0.21\end{aligned}$ & $\begin{aligned} \bar{x} & =3.13 \\
\mathrm{cv} & =0.23\end{aligned}$ \\
\hline Chile & 1.17 & 2.75 & 1.22 & 2.38 & 1.69 & 2.46 & $\begin{array}{c}\bar{x}=1.48 \\
\mathrm{cv}=0.30\end{array}$ & $\begin{array}{c}\bar{x}=2.53 \\
\mathrm{cv}=0.30\end{array}$ \\
\hline Australia & 2.00 & 3.50 & 1.50 & 3.00 & 3.00 & 4.00 & $\begin{array}{c}\bar{x}=2.29 \\
\mathrm{cv}=0.33\end{array}$ & $\begin{array}{c}\bar{x}=3.56 \\
\mathrm{cv}=0.23\end{array}$ \\
\hline Russia & 2.10 & 3.50 & 2.00 & 3.00 & 2.17 & 3.67 & $\begin{array}{c}\bar{x}=2.11 \\
\mathrm{cv}=0.22\end{array}$ & $\begin{array}{c}\bar{x}=3.44 \\
\mathrm{cv}=0.21\end{array}$ \\
\hline Switzer-land & 2.00 & 3.00 & 1.50 & 2.75 & 2.00 & 3.50 & $\begin{array}{l}\bar{x}=1.83 \\
\mathrm{cv}=0.22\end{array}$ & $\begin{array}{l}\bar{x}=3.13 \\
\mathrm{cv}=0.24\end{array}$ \\
\hline Germany & 2.00 & 3.60 & 1.50 & 3.00 & 2.33 & 3.83 & $\begin{array}{l}\bar{x}=2.00 \\
\mathrm{cv}=0.32\end{array}$ & $\begin{array}{l}\bar{x}=3.53 \\
\mathrm{cv}=0.24\end{array}$ \\
\hline $\begin{array}{l}\text { United } \\
\text { Kingdom }\end{array}$ & 2.00 & 3.42 & 1.50 & 2.63 & 2.33 & 3.50 & $\begin{array}{l}\bar{x}=2.00 \\
\mathrm{cv}=0.29\end{array}$ & $\begin{array}{l}\bar{x}=3.26 \\
\mathrm{cv}=0.22\end{array}$ \\
\hline Saudi Arabia & 2.00 & 3.35 & 2.00 & 2.63 & 3.00 & 2.79 & $\begin{array}{c}\bar{x}=2.40 \\
\mathrm{cv}=0.23\end{array}$ & $\begin{array}{c}\bar{x}=2.92 \\
\mathrm{cv}=0.28\end{array}$ \\
\hline Turkey & 1.84 & 2.63 & 1.78 & 1.82 & 1.95 & 2.36 & $\begin{array}{l}\bar{x}=1.88 \\
\mathrm{cV}=0.21\end{array}$ & $\begin{array}{c}\bar{x}=2.31 \\
\mathrm{cv}=0.40\end{array}$ \\
\hline Syria & 1.00 & 2.00 & 1.00 & 1.67 & 1.50 & 1.71 & $\begin{array}{l}\bar{x}=1.25 \\
\mathrm{cv}=0.40\end{array}$ & $\begin{array}{l}\bar{x}=1.80 \\
\mathrm{cv}=0.44\end{array}$ \\
\hline
\end{tabular}


Table A2. Cont.

\begin{tabular}{ccccccccc}
\hline & \multicolumn{2}{c}{$\begin{array}{c}\text { Industry Experts and } \\
\text { Representatives of } \\
\text { Business Associations }\end{array}$} & \multicolumn{2}{c}{$\begin{array}{c}\text { Representatives of the } \\
\text { Public Administration }\end{array}$} & \multicolumn{2}{c}{$\begin{array}{c}\text { Representatives } \\
\text { of Academia }\end{array}$} & \multicolumn{2}{c}{$\begin{array}{c}\text { Overall Mean }(\bar{x}) \text { and } \\
\text { Coefficient of Variation (cv) }\end{array}$} \\
\hline Country & Magnitude & $\begin{array}{c}\text { Degree } \\
\text { of Impact }\end{array}$ & Magnitude & $\begin{array}{c}\text { Degree } \\
\text { of Impact }\end{array}$ & Magnitude & $\begin{array}{c}\text { Degree } \\
\text { of Impact }\end{array}$ & $\begin{array}{c}\text { Magnitude } \\
\text { of Impact }\end{array}$ \\
\hline Morocco & 1.34 & 2.60 & 1.78 & 2.00 & 1.86 & 2.29 & $\begin{array}{c}\bar{x}=1.75 \\
\mathrm{cv}=0.26\end{array}$ & $\begin{array}{c}\bar{x}=2.31 \\
\mathrm{cv}=0.41\end{array}$ \\
\hline Algeria & 1.50 & 2.37 & 2.00 & 1.68 & 2.00 & 2.06 & $\begin{array}{c}\bar{x}=1.91 \\
\mathrm{cv}=0.16\end{array}$ & $\begin{array}{c}\bar{x}=2.06 \\
\mathrm{cv}=0.36\end{array}$ \\
\hline Egypt & 1.00 & 2.00 & 1.22 & 1.69 & 1.38 & 1.81 & $\begin{array}{c}\bar{x}=1.28 \\
\mathrm{cv}=0.22\end{array}$ \\
\hline
\end{tabular}

Note: Values represent mean annual growth on a four-point scale from "very moderate increase" to "very sharp increase", and mean impact on a five-point scale from "insignificant" to "very significant".

\section{References}

1. Anania, G.; Pupo-D'Andrea, M.R. The Global Market for Olive Oil: Actors, Trends, Policies, Prospects and Research Needs. TRADEAG FP6 Proj. Work. Pap. 2007, 8, 2.

2. Lybbert, T.J.; ElAbed, G. An Elixir for Development? Olive Oil Policies and Poverty Alleviation in the Middle East and North Africa. Dev. Policy Rev. 2013, 31, 485-506. [CrossRef]

3. Mili, S.; Rodríguez-Zuñiga, M. Exploring future developments in international olive oil trade and marketing: A Spanish perspective. Agribus. Int. J. 2001, 17, 397-415. [CrossRef]

4. Pomarici, E.; Vecchio, R. The Italian olive oil industry in the global competitive scenario. Agric. Econ. 2013, 59, 361-372. [CrossRef]

5. EU Agricultural Outlook for Markets, Income and Environment 2020-2030. Available online: https:/ / ec.europa.eu/info/sites / info/files/food-farming-fisheries/farming/documents/agricultural-outlook-2020-report_en.pdf (accessed on 17 December 2020).

6. Mili, S. Market Dynamics and Policy Reforms in the Olive Oil Sector: A European Perspective. In Traditional Food Production and Rural Sustainable Development. A European Challenge; Noronha, T., Nijkamp, P., Rastoin, J.L., Eds.; Ashgate Publishing: Surrey, UK, 2009; pp. 215-238.

7. EU Member States in Agri-Food World Markets: Current Competitive Position and Perspectives. Brussels, European Parliament's Committee on Agriculture and Rural Development, Directorate-General for Internal Policies. Available online: https: / www. europarl.europa.eu/RegData/etudes/STUD/2014/514006/IPOL_STU(2014)514006_EN.pdf (accessed on 24 November 2020).

8. Barjol, J.L. L'économie mondiale de l'huile d'olive (The global olive oil economy). OLC 2014, 21, D502.

9. Cohard, J.C.R.; Martínez, J.D.S.; Gallego-Simón, V.-J. The upgrading strategy of olive oil producers in Southern Spain: Origin, development and constraints. Rural. Soc. 2017, 26, 30-47. [CrossRef]

10. World Olive Oil Figures. Available online: www.internationaloliveoil.org/estaticos/view/131-world-olive-oil-figures (accessed on 20 January 2021).

11. Mili, S. Olive Oil Marketing on Non-traditional Markets: Prospects and Strategies. New Medit. 2006, 5, $27-37$.

12. United States International Trade Commission. Olive Oil: Conditions of Competition between U.S. and Major Foreign Supplier Industries; USITC: Washington, DC, USA, 2013.

13. Sánchez-Martínez, J.; Garrido-Almonacid, A. Olive cultivation in the era of globalization. Sci. Technol. Dev. J. Soc. Sci. Humanit. 2019, 2, 60-71. [CrossRef]

14. Alimarket. Informes Anuales del Sector de Aceites (Annual edible oils reports); Publicaciones Alimarket: Madrid, Spain, 2016.

15. Technical Guidance for Deriving Environmental Quality Standards. Common Implementation Strategy for the Water Framework Directive (2000/60/EC), Guidance Document No. 27; European Communities: Brussels, Belgium, 2011; Available online: http: / / ec.europa.eu (accessed on 12 March 2013).

16. Mili, S. Incidence des réformes des politiques agro-commerciales de l'Union européenne sur la filière oléicole tunisienne (Impact of the EU agri-trade policy reforms on the Tunisian olive sector). Lettre l'ONAGRI 2018, 4, 12-18.

17. Commission Implementing Regulation (EU) 2016/605 of 19 April 2016 Opening and Providing for the Administration of a Temporary Tariff Quota for Olive Oil Originating in Tunisia and Amending Regulation (EC) No 1918/2006. Available online: https:/ / eur-lex.europa.eu/legal-content/EN/TXT/PDF/?uri=CELEX:32016R0605\&from=EN (accessed on 9 September 2020).

18. Economic Analysis of the olive Sector. Available online: https://www.oliveoilmarket.eu/economic-analysis-of-the-olive-sectoreuropean-commission (accessed on 15 September 2020).

19. Zampounis, V. Olive oil in the world market. In Olive Oil Chemistry and Technology; Boskou, D., Ed.; AOCS Press: Champaign, IL, USA, 2006; pp. 21-39.

20. Market Situation in the Olive Oil and Table Olives Sectors. Available online: https://ec.europa.eu/info/sites/info/files/ food-farming-fisheries/plants_and_plant_products/documents/market-situation-olive-oil-table-olives_en.pdf (accessed on 13 January 2021). 
21. Finley, J.-C.; Parente, F. A 30-year retrospective case analysis in the Delphi of cognitive rehabilitation therapy. Technol. Forecast. Soc. Chang. 2019, 138, 254-260. [CrossRef]

22. Linstone, H.A.; Turoff, M. Introduction. In The Delphi Method: Techniques and Application; Linstone, H.A., Turoff, M., Eds.; Addison-Wesley: Reading, PA, USA, 1975; pp. 3-12.

23. Parente, R.; Anderson-Parente, J. A case study of long-term Delphi accuracy. Technol. Forecast. Soc. Chang. 2011, 78, $1705-1711$. [CrossRef]

24. Toppinen, A.; Pätäri, S.; Tuppura, A.; Jantunen, A. The European pulp and paper industry in transition to a bio-economy: A Delphi study. Futures 2017, 88, 1-14. [CrossRef]

25. Ilbery, B.; Maye, D.; Kneafsey, M.; Jenkins, T.; Walkley, C. Forecasting food supply chain developments in lagging rural regions: Evidence from the UK. J. Rural. Stud. 2004, 20, 331-344. [CrossRef]

26. Czinkota, M.R.; Ronkainen, I.A. A forecast of globalization, international business and trade: Report from a Delphi study. J. World Bus. 2005, 40, 111-123. [CrossRef]

27. Landeta, J. Current validity of the Delphi method in social sciences. Technol. Forecast. Soc. Chang. 2006, 73, 467-482. [CrossRef]

28. Rowe, G.; Wright, G. The Delphi technique as a forecasting tool: Issues and analysis. Int. J. Forecast. 1999, 15, 353-375. [CrossRef]

29. Popper, R. How are foresight methods selected? Foresight 2008, 10, 62-89. [CrossRef]

30. Green, K.; Armstrong, J.S.; Graefe, A. Methods to Elicit Forecasts from Groups: Delphi and Prediction Markets Compared. Foresight Int. J. Appl. Forecast. 2007, 8, 17-20.

31. Mukherjee, N.; Hugé, J.; Sutherland, W.J.; McNeill, J.; van Opstal, M.; Dahdouh-Guebas, F.; Koedam, N. The Delphi technique in ecology and biological conservation: Applications and guidelines. Methods Ecol. Evol. 2015, 6, 1097-1109. [CrossRef]

32. Fischer, R.G. The Delphi Method: A description, review, and criticism. J. Acad. Librariansh. 1978, 4, 64-70.

33. Henchion, M.; McIntyre, B. Developments in the Irish Food Supply Chain: Impacts and Responses by SMEs. J. Int. Food Agribus. Mark. 2004, 16, 103-122. [CrossRef]

34. Tran, T.; Trinh, T.-P.-T.; Le, C.-M.; Hoang, L.-K.; Pham, H.-H. Research as a Base for Sustainable Development of Universities: Using the Delphi Method to Explore Factors Affecting International Publishing among Vietnamese Academic Staff. Sustainability 2020, 12, 3449. [CrossRef]

35. Linstone, H.A.; Turoff, M. Delphi: A brief look backward and forward. Technol. Forecast. Soc. Chang. 2011, 78, 1712-1719. [CrossRef]

36. von der Gracht, H.A. Consensus measurement in Delphi studies. Review and implications for future quality assurance. Technol. Forecast. Soc. Chang. 2012, 79, 1525-1536. [CrossRef]

37. Glerum, A.; Atasoy, B.; Bierlaire, M. Using semi-open questions to integrate perceptions in choice models. J. Choice Model. 2014, 10, 11-33. [CrossRef]

38. Charbonneau, D.H. Demystifying Survey Research: Practical Suggestions for Effective Question Design. Évid. Based Libr. Inf. Pr. 2007, 2, 46-56. [CrossRef]

39. Song, Y.; Son, Y.-J.; Oh, D. Methodological Issues in Questionnaire Design. J. Korean Acad. Nurs. 2015, 45, 323-328. [CrossRef]

40. Arvidsson, R. On the use of ordinal scoring scales in social life cycle assessment. Int. J. Life Cycle Assess. 2018, 24, 604-606. [CrossRef]

41. Hassal, J. Methods of Analysing Ordinal/Interval Questionnaire Data using Fuzzy Mathematical Principles; University of Wolverhampton Working Paper Series: Wolverhampton, UK, 1999.

42. Marateb, H.R.; Mansourian, M.; Adibi, P.; Farina, D. Manipulating measurement scales in medical statistical analysis and data mining: A review of methodologies. J. Res. Med. Sci. 2014, 19, 47-56.

43. Kampen, J.; Swyngedouw, M. The Ordinal Controversy Revisited. Qual. Quant. 2000, 34, 87-102. [CrossRef]

44. Knapp, T.R. Treating ordinal scales as interval scales: An attempt to resolve the controversy. Nurs. Res. 1990, 39, 121-123. [CrossRef]

45. Baker, B.O.; Hardyck, C.D.; Petrinovich, L.F. Weak Measurements vs. Strong Statistics: An Empirical Critique of S. S. Stevens' Proscriptions nn Statistics. Educ. Psychol. Meas. 1966, 26, 291-309. [CrossRef]

46. Labovitz, S. Some Observations on Measurement and Statistics. Soc. Forces 1967, 46, 151-160. [CrossRef]

47. Likert, R. A technique for the measurement of attitudes. Arch. Psychol. 1932, 140, 1-55.

48. Carifio, J.; Perla, R. Resolving the 50-year debate around using and misusing Likert scales. Med. Educ. 2008, 42, 1150-1152. [CrossRef] [PubMed]

49. Corbetta, P. Social Research: Theory, Methods and Techniques; SAGE Publications, Inc.: Thousand Oaks, CA, USA, 2003.

50. Landeta, J. El Método Delphi: Una Técnica de Previsión Para la Incertidumbre (The Delphi Method: A Forecasting Technique for Uncertainty); Ariel: Barcelona, Spain, 1999.

51. Chan, P.; Lee, M.-H. Developing Sustainable City Indicators for Cambodia through Delphi Processes of Panel Surveys. Sustainability 2019, 11, 3166. [CrossRef]

52. Devaney, L.; Henchion, M. Who is a Delphi 'expert'? Reflections on a bioeconomy expert selection procedure from Ireland. Future 2018, 99, 45-55. [CrossRef]

53. Hatcher, T.; Colton, S. Using the internet to improve HRD research: The case of the web-based Delphi research technique to achieve content validity of an HRD-oriented measurement. J. Eur. Ind. Train. 2007, 31, 570-587. [CrossRef] 
54. Okoli, C.; Pawlowski, S.D. The Delphi method as a research tool: An example, design considerations and applications. Inf. Manag. 2004, 42, 15-29. [CrossRef]

55. Powell, C. The Delphi technique: Myths and realities. J. Adv. Nurs. 2003, 41, 376-382. [CrossRef]

56. Hasson, F.; Keeney, S.; McKenna, H. Research guidelines for the Delphi survey technique. J. Adv. Nurs. 2000, 32, 1008-1015. [CrossRef]

57. Hallowell, M.R.; Gambatese, J.A. Qualitative Research: Application of the Delphi Method to CEM Research. J. Constr. Eng. Manag. 2010, 136, 99-107. [CrossRef]

58. Turoff, M.; Hiltz, S.R. Computer-based Delphi process. In Gazing into the Oracle: The Delphi Method and Its Application to Social Policy and Public Health; Alder, M., Ziglio, E., Eds.; Jessica Kingsley: London, UK, 1996; pp. 56-58.

59. Karray, B.; Kanoun, F. Forces, faiblesses, opportunités et menaces de la filière oléicole en Tunisie (Strengths, weaknesses, opportunities and threats in the Tunisian olive oil supply chain). New Medit. 2013, 12, 35-45.

60. Saldanha, J.; Gray, R. The potential for British coastal shipping in a multimodal chain. Marit. Policy Manag. 2002, 29, 77-92. [CrossRef]

61. English, G.M.; Keran, G.L. The prediction of air travel and aircraft technology to the year 2000 using the Delphi method. Transp. Res. 1976, 10, 1-8. [CrossRef]

62. Zinn, J.; Zalokowski, A.; Hunter, L. Identifying Indicators of Laboratory Management Performance: A Multiple Constituency Approach. Heal. Care Manag. Rev. 2001, 26, 40-53. [CrossRef]

63. Dajani, J.S.; Sincoff, M.Z.; Talley, W.K. Stability and agreement criteria for the termination of Delphi studies. Technol. Forecast. Soc. Chang. 1979, 13, 83-90. [CrossRef]

64. Scheibe, M.; Skutsch, M.; Schofer, J. Experiments in Delphi methodology. In The Delphi Method: Techniques and Application; Linstone, H.A., Turoff, M., Eds.; Addison-Wesley: Reading, PA, USA, 1975; pp. 262-287.

65. Wang, J.; Zhang, D.; Javaid, T.; Farooqi, A.; Ma, L.; Deng, D.; Jia, Z. The olive (Olea europaea L.) industry in China: Its status, opportunities and challenges. Agroforest. Syst. 2019, 93, 395-417. [CrossRef]

66. Lazzeri, Y. China: An Emerging Market with High Potential. CIHEAM Watch Lett. 2011, 16, 8-10.

67. Krystallis, A.; Ness, M. Consumer preferences for quality foods from a South European perspective: A conjoint analysis implementation on Greek olive oil. Int. Food Agribus. Manag. Rev. 2005, 8, 62-91.

68. Steinhart, Y.; Mazursky, D.; Kamins, M.A. The process by which product availability triggers purchase. Mark. Lett. 2013, 24, 217-228. [CrossRef]

69. Niklis, D.; Baourakis, G.; Thabet, B.; Manthoulis, G. Trade and Logistics: The Case of the Olive Oil Sector. In MEDITERRA 2014: Logistics and Agro-food Trade. A Challenge for the Mediterranean; Presses de Sciences Po: Paris, France, 2014; pp. $203-226$.

70. Jiménez-Guerrero, J.F.; Gázquez-Abad, J.C.; Mondéjar-Jiménez, J.A.; Huertas-García, R. Consumer Preferences for Olive-Oil Attributes: A Review of the Empirical Literature Using a Conjoint Approach. In Olive Oil—Constituents, Quality, Health Properties and Bioconversions; Boskou, D., Ed.; IntechOpen: London, UK, 2012; pp. 233-246.

71. Menapace, L.; Colson, G.; Grebitus, C.; Facendola, M. Consumers' preferences for geographical origin labels: Evidence from the Canadian olive oil market. Eur. Rev. Agric. Econ. 2011, 38, 193-212. [CrossRef]

72. Tempesta, T.; Vecchiato, D. Analysis of the Factors that Influence Olive Oil Demand in the Veneto Region (Italy). Agriculture 2019, 9, 154. [CrossRef]

73. OECD. Trade Facilitation and the Global Economy; OECD Publishing: Paris, France, 2018.

74. World Bank. Doing Business 2019: Training for Reform; World Bank: Washington, DC, USA, 2019.

75. Xiong, B.; Sumner, D.; Matthews, W. A new market for an old food: The U.S. demand for olive oil. Agric. Econ. 2014, 45, 107-118. [CrossRef]

76. Elleby, C.; Pérez-Domínguez, I.; Adenauerm, M.; Genovese, G. Impacts of the COVID-19 Pandemic on the Global Agricultural Markets. Environ. Resour. Econ. 2020, 76, 1067-1079. [CrossRef]

77. Cranfield, J.A.L. Framing consumer food demand responses in a viral pandemic. Can. J. Agric. Econ. 2020, 68, 151-156. [CrossRef]

78. Short-Term Outlook for EU Agricultural Markets in 2020. Available online: https: / ec.europa.eu/info/sites /info/files/foodfarming-fisheries/farming/documents/short-term-outlook-spring-2020_en.pdf (accessed on 15 January 2021).

79. COVID-19 Impact on Consumer Food Behaviours in Europe. Available online: https://www.eitfood.eu/media/news-pdf/ COVID-19_Study_-_European_Food_Behaviours_-_Report.pdf (accessed on 21 January 2021).

80. Borsellino, V.; Kaliji, S.A.; Schimmenti, E. COVID-19 Drives Consumer Behaviour and Agro-Food Markets towards Healthier and More Sustainable Patterns. Sustainability 2020, 12, 8366. [CrossRef]

81. Food Consumption Habits Will Change for Good. Available online: https:/ /www.consultancy.com.au/news/2200/mckinseyfood-consumption-habits-will-change-for-good (accessed on 28 January 2021).

82. Poppe, K. COVID-19 will Change the Agri-food System-But how? Eurochoices 2020, 19, 20-25. [CrossRef]

83. Kerr, W.A. The COVID-19 pandemic and agriculture: Short- and long-run implications for international trade relations. Can. J. Agric. Econ. 2020, 68, 225-229. [CrossRef]

84. Aday, S.; Aday, M.S. Impact of COVID-19 on the food supply chain. Food Qual. Saf. 2020, 4, 167-180. [CrossRef]

85. Martin, W.J.; Glauber, J.W. Trade policy and food security. In COVID-19 and Trade Policy: Why Turning Inward Won't Work; Baldwin, R.E., Evenett, S.J., Eds.; CEPR Press: London, UK, 2020; pp. 89-101. 
86. Espitia, A.; Rocha, N.; Ruta, M. COVID-19 and Food Protectionism: The Impact of the Pandemic and Export Restrictions on World Food Markets. In COVID-19 and Food Protectionism: The Impact of the Pandemic and Export Restrictions on World Food Markets; The World Bank: Washington, DC, USA, 2020; p. 9253. [CrossRef]

87. Aengenheyster, S.; Cuhls, K.; Gerhold, L.; Heiskanen-Schüttler, M.; Huck, J.; Muszynska, M. Real-Time Delphi in practice-A comparative analysis of existing software-based tools. Technol. Forecast. Soc. Chang. 2017, 118, 15-27. [CrossRef]

88. Gnatzy, T.; Warth, J.; von der Gracht, H.; Darkow, I.-L. Validating an innovative real-time Delphi approach-A methodological comparison between real-time and conventional Delphi studies. Technol. Forecast. Soc. Chang. 2011, 78, 1681-1694. [CrossRef]

89. Salgado, M.; Vieira, A.C.L.; Torres, A.; Oliveira, M.D. Selecting Indicators to Monitor and Assess Environmental Health in a Portuguese Urban Setting: A Participatory Approach. Int. J. Environ. Res. Public Health 2020, 17, 8597. [CrossRef] [PubMed]

90. Bañuls, V.A.; Turoff, M. Scenario construction via Delphi and cross-impact analysis. Technol. Forecast. Soc. Chang. 2011, 78, 1579-1602. [CrossRef]

91. Nowack, M.; Endrikat, J.; Guenther, E. Review of Delphi-based scenario studies: Quality and design considerations. Technol. Forecast. Soc. Chang. 2011, 78, 1603-1615. [CrossRef]

92. Rowe, G.; Wright, G. The Delphi technique: Past, present, and future prospects-Introduction to the special issue. Technol. Forecast. Soc. Chang. 2011, 78, 1487-1490. [CrossRef]

93. Tapio, P.; Paloniemi, R.; Varho, V.; Vinnari, M. The unholy marriage? Integrating qualitative and quantitative information in Delphi processes. Technol. Forecast. Soc. Chang. 2011, 78, 1616-1628. [CrossRef] 